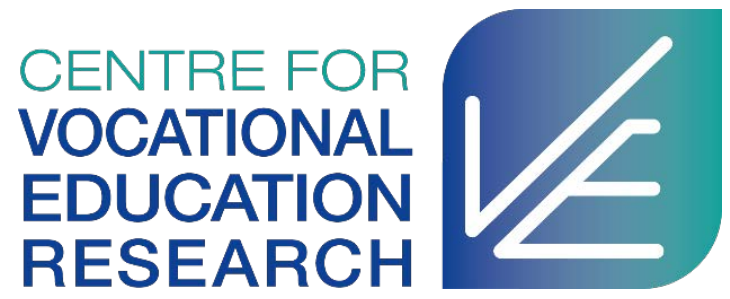

\title{
Skills, Signals, and Employability: An Experimental Investigation
}

Marc Piopiunik, Guido Schwerdt, Lisa Simon, and Ludger Woessmann

Research Discussion Paper 012

February 2018

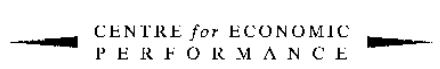


The Centre for Vocational Education Research (CVER) is an independent research centre funded by the UK Department for Education (DfE). CVER brings together four partners: the LSE Centre for Economic Performance; University of Sheffield; National Institute of Economic and Social Research and London Economics.

Any views expressed are those of the authors, and do not represent the views of DfE. For more details on the Centre, go to cver.Ise.ac.uk

Published by:

Centre for Vocational Educational Research

London School of Economics \& Political Science

Houghton Street

London WC2A 2AE

All rights reserved. No part of this publication may be reproduced, stored in a retrieval system or transmitted in any form or by any means without the prior permission in writing of the publisher nor be issued to the public or circulated in any form other than that in which it is published.

Requests for permission to reproduce any article or part of the Working Paper should be sent to the editor at the above address.

(C) M. Piopiunik, G. Schwerdt, L. Simon, and L. Woessmann, February 2018.

THE LONDON SCHOOL 


\title{
Skills, Signals, and Employability: An Experimental Investigation
}

\author{
Marc Piopiunik, Guido Schwerdt, Lisa Simon, and Ludger Woessmann
}

\author{
February 2018
}

\begin{abstract}
As skills of labor-market entrants are usually not directly observed by employers, individuals acquire skill signals. To study which signals are valued by employers, we simultaneously and independently randomize a broad range of skill signals on pairs of resumes of fictitious applicants among which we ask a large representative sample of German human-resource managers to choose. We find that signals in all three studied domains - cognitive skills, social skills, and maturity - have a significant effect on being invited for a job interview. Consistent with the relevance, expectedness, and credibility of different signals, the specific signal that is effective in each domain differs between apprenticeship applicants and college graduates. While GPAs and social skills are significant for both genders, males are particularly rewarded for maturity and females for IT and language skills. Older HR managers value school grades less and other signals more, whereas HR managers in larger firms value college grades more.
\end{abstract}

JEL Classification: J24, J21, 126

Keywords: Signals, cognitive skills, social skills, resume, hiring, labor market

\section{Acknowledgements}

We would like to thank Sascha Becker, David Deming, Armin Falk, Bentley MacLeod, Jesse Rothstein, Miguel Urquiola, Raymundo Vazquez, and seminar participants at Columbia University, UC Berkeley, the ifo Institute, and the annual meetings of the European Economic Association in Lisbon, the German Economic Association in Vienna, the European Association of Labour Economists in St. Gallen, and the CESifo area conference on economics of education in Munich. Katarina Bjelajac Witzheller and Patrick Maus provided capable research assistance. Financial support by the German Federal Ministry of Education and Research for the project "Exit exams as a governance instrument in the school system: The importance of school-leaving grades for the hiring decisions of firms" within the BMBF research priority "Educational Governance" (SteBis) is gratefully acknowledged.

\section{Affiliations:}

Piopiunik: ifo Institute at the University of Munich; CESifo; piopiunik@ifo.de

Schwerdt: Department of Economics, University of Konstanz; CESifo and IZA; guido.schwerdt@unikonstanz.de.

Simon: ifo Institute at the University of Munich; simon@ifo.de.

Woessmann: University of Munich, ifo Institute; CESifo, IZA, and CAGE; woessmann@ifo.de 


\section{Introduction}

Cognitive and non-cognitive skills predict individuals' labor-market performance (e.g., Heckman, Stixrud, and Urzua 2006), but employers cannot directly observe the skills of job applicants. While individuals make costly investments to signal skills to potential employers, it is not well understood which and to what extent signals of different skills affect hiring decisions. A more nuanced empirical investigation of the relative importance of different skill signals - characteristics in which workers have invested - for employability is challenging, because many different and potentially highly correlated signals are considered simultaneously by employers when making hiring decisions, and not all of these signals are typically observed by researchers.

In this paper, we investigate how several different skill signals affect labor-market entry in an experimental setting. Having access to the database of the ifo Personnel Manager Survey, a regular online survey of human-resource (HR) managers representative of German firms, we are able to conduct a survey experiment with 579 HR managers. The experimental design gives us full control over the information set available to firms. We simultaneously randomize several skill signals contained in applicants' CVs, allowing us to exploit independent and exogenous variation in different signals for three broad skill domains: cognitive skills, social skills, and maturity - a trait of potentially particular relevance at labor-market entry.

The choice experiments confront HR managers with resumes of two fictitious job applicants and ask them to indicate the applicant whom they would rather invite for a job interview in their firm. The only information on the applicants available to HR managers are the elements of the resumes, which were carefully selected based on the results of a pre-study in which we conducted a series of qualitative interviews with HR managers to identify pieces of information typically included in resumes of real applicants in Germany. Because the skill signals that are effectively relevant might differ substantially between secondary-school and college graduates due to differing relevance, expectedness, and credibility of various skill signals, part of the HR managers receive applications from secondary-school graduates for an apprentice position and the other part receive applications from college graduates in business administration for a business trainee position. ${ }^{1}$

\footnotetext{
${ }^{1}$ To avoid unrealistic situations, the resumes are adjusted to the firm of the HR manager. Most importantly, using information on the educational composition of the firms' workforce that we elicited in a pre-survey, secondary-school graduates applying for an apprentice position are presented only to HR managers in firms that currently offer apprenticeship positions. Similarly, applications of college graduates are only shown to HR managers whose firms employ college graduates.
} 
We complement these choice experiments with a questionnaire on HR managers' personal characteristics which allows us to investigate heterogeneities across HR managers. In the questionnaire, we also ask HR managers to indicate the importance they attach to various resume attributes (e.g., college grades and IT skills) of actual job applicants in their firm. This enables us to assess whether self-reported hiring preferences are consistent with the decisions in the choice experiment between the fictitious candidates' resumes.

We find that signals in all three domains - cognitive skills, social skills, and maturity affect the probability of being invited for a job interview. Cognitive skills are signaled by grade-point averages (GPAs, referring to school GPA for secondary-school graduates and to college GPA for college graduates), IT skills, fluency in English, and a second foreign language. Social skills are signaled by social volunteering and team sports (as opposed to single sports). Maturity is signaled by being older (within the same school cohort) and length of internship. GPAs prove important for both genders, with a stronger effect for college graduates than for secondary-school graduates. IT and language skills are particularly relevant for females. Social skills are highly relevant for both genders and particularly important for secondary-school graduates entering the labor market at a young age. Maturity is particularly relevant for males, especially for secondary-school graduates.

These heterogeneities by labor-market entry age and gender are consistent with varying relevance, expectedness, and credibility of the different skill signals in different contexts. Gender differences in the effects of language skills, IT skills, and maturity are generally in line with gender stereotyping. Social skills are most effectively signaled by social volunteering among secondary-school graduates but by engaging in team sports among college graduates, possibly reflecting limited credibility of volunteering activities of older individuals who may behave strategically. Furthermore, we find that skill signals with straightforward verifiability in real hiring situations, such as GPAs (available on transcripts that are usually included in applications in Germany), internships, and age, tend to have higher returns than skills that are more costly to verify, such as language skills and social volunteering, in particular at large firms.

We also find heterogeneities with respect to HR managers' personal characteristics. For secondary-school graduates applying for an apprentice position, managing directors and older HR managers put less weight on school GPAs, but instead more weight on IT skills, social volunteering, and experience through internships. Among college graduates, HR managers in large firms value college GPAs more, possibly due to a more standardized procedure of applicant selection. Adding plausibility to our experimental setup, we further find that the 
self-reported hiring priorities of HR managers tend to be in line with their decisions between the fictitious resumes in the choice experiments.

Overall, our results indicate that a broad range of skill signals does indeed causally affect employment chances at labor-market entry. Employers appear to value skill signals in several different domains. While situated in a specifically designed experimental setting, the results add an important dimension to our understanding of how labor markets process and use information on skills. When observational data indicate that, for example, high-school grades are associated with labor-market outcomes, it remains unclear whether employers really value grades or whether the association captures other productivity aspects that happen to be correlated with grades, whereas grades are potentially never conscientiously observed by employers. Even in the setting of a convincing natural experiment, it is hard to imagine a research design that can separately identify independent exogenous variation in different skill dimensions such as GPAs and other skill signals such as social engagement. Our experimental results indicate that employers do indeed care about signals such as high-school GPAs, social volunteering, and internships, adding to the scientific knowledge on the importance of skills and signals for labor-market outcomes. The results also provide an indication about which signals may be particularly relevant for whom. The observed effect heterogeneities by stage of application (school vs. college graduates), gender of applicants, and traits of HR decision-makers suggest that different signals are regarded as relevant, expected, and credible in different situations.

Our research design adds to the literature on CV studies. However, this literature almost exclusively focuses on discrimination in the labor market, investigating labor-market effects of innate characteristics such as gender and race (see Rich 2014, Neumark 2016, and Bertrand and Duflo 2016 for overviews and Section 2.2 for greater detail). By contrast, we are interested in the returns to skill investments that are used as signals of productivity on resumes. Thus, we focus on the labor-market effects of intentionally acquired characteristics. ${ }^{2}$ A recent exception in the existing literature is the study by Deming et al. (2016) who investigate the employability impact of for-profit online college degrees. Our study, in turn, investigates the employability impact of a broad range of acquired signals in different skill domains. ${ }^{3}$

\footnotetext{
${ }^{2}$ To abstract from the aspects studied in the discrimination literature, we keep gender fixed within CV pairs and use only standard German names.

${ }^{3}$ A general limitation of the CV study literature is that only the first stage of the application process - the interview invitation - is observed, but not actual job offers or wages. This limitation naturally also applies to our study.
} 
An important difference between the existing CV study literature and our study is that statistical discrimination based on innate characteristics is typically considered unfair in the sense that it is based on circumstances that are beyond a person's control (Roemer 1998). ${ }^{4}$ In contrast, differential treatment of job applicants is generally considered fair to the extent that it is based on differences in signals that reflect differences in ability or effort. According to theories of job market signaling and screening, these skill signals have to be acquired by individuals since actual skills are not directly observed by employers at the application stage (see the surveys by Weiss 1995 and Riley 2001). ${ }^{5}$

A large literature has established that labor-market outcomes are associated with different types of skills. Skills may be reflected through educational degrees (e.g., Card 1999; Heckman, Lochner, and Todd 2006) or more directly observed in terms of cognitive skills (e.g., Bowles, Gintis, and Osborne 2001; Hanushek and Woessmann 2008). Social skills seem to have become more important on the labor market during recent decades, partly due to the growing importance of team production (Deming 2017). ${ }^{6}$ Likewise, signals of maturity, including personality traits such as conscientiousness, commitment, and perseverance, are strongly related to labor-market outcomes (Almlund et al. 2011). Despite the vast evidence that these different types of skills are associated with labor-market success, it is unclear whether signals of these skills that can be observed at the application stage have a causal impact on the employability at career start.

In contrast to most existing CV studies, HR managers in our study are fully aware that they are dealing with fictitious job applicants. As we do not study discrimination against certain groups of applicants (e.g., women, blacks, or foreigners), we are less concerned about social desirability bias in HR managers' behavior, which is a primary motivation for not being transparent about the true nature of applications in conventional CV studies. Apart from not deceiving participants, the transparency of our research design has several advantages. First, existing discrimination studies put substantial costs on the hiring systems of firms. Second, the flooding of online portals with fictitious CVs might lead to artificial results because initial hiring decisions are increasingly computerized, whereas final job offers are made by HR managers. Instead, we make use of evaluations by those HR managers who actually make the

\footnotetext{
${ }^{4}$ According to the nondiscrimination principle, individuals who compete with each other for positions in society should be judged only on attributes that are relevant to the performance of the duties of the respective position. Therefore, attributes such as gender or race should not be taken into account.

${ }^{5}$ Throughout the paper, we refer to signaling simply as the revelation of otherwise unobserved information, without any claim about whether the signaling process is productive or unproductive from a welfare perspective.

${ }^{6}$ On the importance of non-cognitive skills more generally, see also Heckman, Stixrud, and Urzua (2006), Borghans et al. (2008), and Almlund et al. (2011).
} 
hiring decisions in their firms. Third, in contrast to studies that contact job portals, our survey-based approach enables us to collect information about the decision-makers' personal characteristics and about their hiring preferences. ${ }^{7}$ This allows both investigating effect heterogeneity by HR managers’ characteristics and assessing whether self-reported hiring priorities are consistent with actual decisions in an experimental setup. Fourth, in our setting we have complete information on all applicants that an HR manager faces. In contrast, researchers sending fictitious resumes to real job openings do not have information on the characteristics of the real job applicants for the same position. The distribution of relevant resume characteristics of the other job applicants, however, likely affects job interview decisions. $^{8}$

The remainder of the paper proceeds as follows. Section 2 presents a conceptual framework of the role of skills and their signals on the labor market and discusses the related literature in greater detail. Section 3 describes the experimental design of our CV study. Section 4 reports the baseline results of the choice experiments. Section 5 investigates heterogeneous effects for different HR managers. Section 6 concludes.

\section{Conceptual Framework on Skills, Signals, and Labor Markets, with Relation to the Literature}

As background for our experimental setup, based on the existing literature we derive a conceptual framework on how different skills may affect labor-market outcomes, how this effect depends on the extent to which the skills are observed by employers, and how the importance of skill signals may vary with the quality of the signal and the context. We then discuss how a randomized CV study can be used to elicit exogenous and independent variation in different skill signals and indicate how the question of effects of costly skill signals differs from most of the existing CV study literature. Based on the conceptual framework and the existing knowledge in the literature, we then specify our main research question as well as several hypotheses on effect heterogeneities based on the relevance, expectedness, and credibility of specific skill signals in different contexts.

\footnotetext{
${ }^{7}$ In addition, we have access to rich information on the firms, including the educational composition of their workforce.

${ }^{8}$ For example, assuming that employers value math skills, the estimated returns to math skills will be lower if most real applicants possess high math skills (since this lowers the probability that a fictitious applicant with high math skills gets invited to a job interview), compared to a situation where hardly any real applicant possesses high math skills. Since we have complete information on the distribution of characteristics of all applicants, the magnitudes of the estimated skill signals are directly comparable with each other and not influenced by resume characteristics of unknown job applicants.
} 


\subsection{Skills, Signals, and Labor-Market Outcomes}

Employability of individuals depends on their marketable skills in which they make a variety of investments. Formal education is one of these investments. Numerous studies, for example, show that more schooling and higher educational degrees lead to more success on the labor market (see Card 1999 and Heckman, Lochner, and Todd 2006 for reviews). However, while the reduced-form effects of investments in skills on labor-market success are well documented, it is less well understood how these effects arise. Several aspects complicate a more nuanced investigation of the underlying mechanisms.

Marketable skills are not unidimensional. The specific labor-market impacts of different domains of skills have been the subject of a growing literature. Based on survey or administrative data, several studies investigate the importance of cognitive skills such as achievement on standardized tests on labor-market outcomes. This literature is extensively reviewed in Bowles, Gintis, and Osborne (2001) and Hanushek and Woessmann (2008). Early studies $^{9}$ as well as more recent investigations (Chetty et al. 2011; Hanushek et al. 2015, 2017) document that cognitive skills are positively related to employment and earnings.

There is also abundant evidence highlighting the importance of non-cognitive skills. While non-cognitive skills are often used as a vague term for any skill that is not cognitive (and, in fact, many skills generally referred to as non-cognitive contain a strong cognitive component), an increasing literature investigates different empirically clearly specified skills in the non-cognitive domain. One important dimension of non-cognitive skills is social skills. Deming (2017) argues that the importance of social skills on the labor market is growing, with the fastest-growing occupations requiring a substantial amount of interpersonal interactions. His results support a model of team production where workers trade tasks to exploit their comparative advantage. In this setting, social skills reduce coordination costs, allowing workers to specialize and trade more efficiently. Thus, social skills such as the willingness to cooperate may make workers more productive in team production. ${ }^{10}$ This may be particularly important in occupations with a high complementarity between cognitive and social skills (Weinberger 2014). Recent evidence suggests that social volunteering may be used to credibly signal willingness to cooperate (Baert and Vujić 2016; Heinz and Schumacher 2017), but social volunteering may also be correlated with other skills valued by employers.

\footnotetext{
${ }^{9}$ E.g., Bishop (1989); Murnane, Willett, and Levy (1995); Neal and Johnson (1996); and Mulligan (1999).

${ }^{10}$ In the context of a lab experiment, Englmaier and Gebhardt (2016) find direct evidence of a link between productivity and cooperative behavior measured by contributions in a public good game.
} 
Another dimension of non-cognitive skills that may be particularly relevant at the labor-market entrance stage are personality traits that include maturity, conscientiousness, perseverance, and curiosity (see Almlund et al. 2011 for a review). For example, Heckman, Humphries, and Mader (2011) find that even conditional on cognitive skills, high-school graduates outperform GED recipients in terms of labor-market outcomes and show that this difference is driven by personality. This is in line with other findings on a positive link between personality traits and labor-market outcomes. ${ }^{11}$

Any observational study on the impact of skills on employability, however, faces the challenge that researchers do not know whether skills are actually observed by employers. In contrast to innate characteristics such as gender and race, cognitive skills, social skills, and maturity are typically not directly observable. Thus, employability might be primarily a function of signals of these skills rather than the skills themselves. Educational credentials, grades, and extracurricular activities are just a few prominent examples of such skill signals.

A large literature explores the role of costly skill signals in determining labor-market outcomes. ${ }^{12}$ Several studies investigate the signaling value of educational credentials (e.g., Tyler, Murnane, and Willett 2000; Clark and Martorell 2014). The importance of skill signals may, however, crucially depend on other factors. For example, it seems intuitive that skill signals are more important for labor-market entrants than for workers with substantial experience. In fact, Altonji and Pierret (2001) find evidence for employer learning about the true skills of workers over time. In addition, Arcidiacono, Bayer, and Hizmo (2010) show that ability is observed nearly perfectly for college graduates, but is revealed to the labor market more gradually for high-school graduates.

More generally, the importance of a specific skill signal may depend on the perceived quality of the signal. For example, MacLeod et al. (2017) find that college reputation in Colombia is correlated with graduates' earnings, but the availability of the additional skill signal of a college exit exam reduces the returns to reputation. For Germany, Schwerdt and Woessmann (2017) show that the information value of high-school grades depends on whether these grades were obtained in local or centralized exams. In addition, Lang and Manove (2011) argue that education is generally a more valuable signal of productivity for blacks than for whites. Thus, the value of a skill signal may also depend on stereotypes: if members of a

${ }^{11}$ E.g., Heckman, Stixrud, and Urzua (2006); Mueller and Plug (2006); Heineck and Anger (2010); and Lindqvist and Vestman (2011).

${ }^{12}$ See Spence (1973), Arrow (1973), and Stiglitz (1975) for seminal contributions and Weiss (1995) and Riley (2001) for surveys. 
specific group are perceived to have certain skills while non-members are not, signals for the same skills may matter more for non-members.

\subsection{Studies: Innate Characteristics vs. Acquired Signals}

A key conceptual problem is that skills, as well as signals thereof, are typically highly correlated across domains. Arguably, many types of skill investments do not only increase one particular type of skill, but affect the development of several dimensions of skills. In addition, the acquisition of actual skills and skill signals may depend on other determinants of employability such as innate characteristics. As a consequence, it is empirically challenging to identify the isolated effect of an increase in one particular skill signal based on observational data. The key problem is that other determinants of employability are likely not observed by the econometrician, but may be observed by the employer. To credibly estimate the relative importance of different skill signals on employability, it is therefore crucial to obtain independent exogenous variation in the different skill domains.

Randomized CV studies offer a methodological solution to this identification problem. In these studies, fictitious applications with fictitious resumes are sent to numerous employers currently offering jobs. The resumes are designed to carefully match on all individual characteristics that matter for employability so that the fictitious applicants are identical except for the characteristic whose impact the researcher is investigating. This research design has two key advantages. First, the experimentally generated variation in resume characteristics solves the identification problem. Second, the econometrician knows exactly all the signals that the employer observes for the fictitious applicants. A common drawback of this research design, however, is that actual job offers and wages are not observed, but only the first stage of the application process, i.e., the invitation for a job interview.

Most studies using randomized resumes are motivated by research questions addressing different types of discrimination in the labor market (see Rich 2014, Neumark 2016, and Bertrand and Duflo 2016 for recent overviews). As a consequence, nearly all existing CV studies focus on the impact of innate characteristics such as race (e.g., Bertrand and Mullainathan 2004), gender (e.g., Booth and Leigh 2010), age (e.g., Riach 2015), immigrant status (e.g., Oreopoulos 2011), ${ }^{13}$ phenotype (e.g., Arceo-Gomez and Campos-Vazquez 2014),

\footnotetext{
${ }^{13}$ While migration status is not innate, individuals cannot simply invest in this characteristic as in cognitive and non-cognitive skills.
} 
or beauty (e.g., Ruffle and Shtudiner 2010). ${ }^{14}$ A differential treatment of job applicants by firms based on these innate characteristics will generally be viewed as unfair - e.g., according to Roemer's (1998) concept of equality of opportunity. In contrast, our focus is on characteristics in which individuals can invest.

\subsection{Main Research Question and Contextual Heterogeneity: Relevance, Expectedness, and Credibility of Skill Signals}

The conceptual framework, together with the review of the existing literature, implies some important open research questions that we address in this paper. Our main question of interest is whether and which acquired signals of skills in different domains - cognitive skills, social skills, and maturity - have a causal effect on employability. To address this question, we simultaneously and independently randomize several skill signals in the framework of a CV study.

To obtain a more nuanced view of how skill signals affect employment prospects, we also aim to investigate how the effectiveness of different types of skill signals varies in different settings. As indicated, different skills may be viewed as relevant and expected in different contexts, and different signals may be viewed as credible. We thus set out to test how the relevance, expectedness, and credibility of different skill signals affect their effectiveness in different contexts.

First, given the differential observability of skills for graduates from high school and college, we study the relevance of different skill domains for graduates of lower-secondary school who apply for an apprenticeship as opposed to college graduates. Further aspects of skill relevance may give rise to heterogeneity by gender (if employers have stereotypes about how different genders will be employed in the workplace), firms (e.g., relevance of different skills in different sectors), and types of HR managers (e.g., more or less experienced managers). The investigation of whether the importance of skill signals depends on the characteristics of HR managers is typically not feasible when sending fictitious applications to real job openings.

Second, certain groups of applicants may be generally expected to be equipped with certain skills, reducing the payoff to respective signals. For example, employers may expect college

${ }^{14}$ Notable exceptions of randomized CV studies that investigate the effects of including information on a particular cognitive or non-cognitive skill on the resume include Koedel and Tyhurst (2012) for math skills, Protsch and Solga (2015) for school grades and teacher evaluations, Humburg and van der Velden (2015) for occupation-specific field of study and professional experience, Kübler and Schmid (2015) for age and additional training, and Baert and Vujić (2016) and Heinz and Schumacher (2017) for social volunteering. In a non-randomized pre-post setup of a CV study, Falk, Lalive, and Zweimüller (2005) study the effect of a training course meant to raise basic computer skills on job interview invitations. 
graduates to be equipped with basic language and IT skills anyway, but do not expect the same skills from secondary-school graduates. A further example of expectedness is another form of gender stereotyping. For example, if HR managers expect boys to be affine to computers in general, signaling good IT skills may have a higher value for girls than for boys.

Third, the value of a signal may depend on its credibility. One aspect of credibility is the extent to which a signal can be verified, which may be easier for GPAs than for social skills. Another aspect of credibility refers to the possibility of strategic behavior of job applicants. For example, even rather unsociable people may choose to signal social volunteering if they expect such signals to be rewarded in the labor market. In such a setting, social volunteering may lose credibility as a signal of social skills and may be replaced by other signals that are less subject to strategic behavior.

By studying these different forms of heterogeneities in the relevance, expectedness, and credibility of different skill signals, we aim to shed light on how skill signals function in the labor market.

\section{Experimental Design}

To investigate the importance of skill signals for employability, we conduct an online survey experiment with randomized CVs among German HR managers.

\subsection{Choice Experiments in an HR Manager Survey}

Participants in our online survey experiment are HR managers who participate in the ifo Personnel Manager Survey. ${ }^{15}$ The ifo Institute, an independent economic research institute that regularly conducts business surveys including Germany's main business climate index, executes this quarterly survey of personnel managers to construct an index of the use of different personnel management instruments and to investigate current topics of personnel policy. We conducted our survey as a special additional survey in August 2016. The firms covered by the database are a representative sample of firms in Germany.

We confront each HR manager with two choice experiments. In each choice experiment, we ask HR managers to compare resumes of two fictitious applicants (either two secondary-school graduates or two college graduates), which are presented side by side on the same screen, and to choose the candidate they would rather invite for an interview in their firm. We force HR managers to select exactly one out of the two candidates to mimic the fact that

15 For more information on the ifo Personnel Manager Survey, see https://www.cesifo-group.de/ifoHome/facts/Survey-Results/Personalleiterbefragung.html. 
HR managers ultimately have to make choices and to increase statistical power in the empirical analysis. ${ }^{16}$ HR managers complete the two choice experiments sequentially and are not able to revise their decisions.

To present realistic candidates to HR managers - either secondary-school graduates or college graduates - we elicited information on the educational structure of the firms' workforce in a pre-survey, conducted in the context of a regular ifo Personnel Manager Survey prior to our main survey. Based on the share of employees with college degrees and the presence of apprentices in the firm, we split firms in our database into two groups. HR managers in firms with a high share of college-educated employees were shown resumes of fictitious college graduates applying for a fictitious graduate trainee position. ${ }^{17}$ The second group of HR managers, who had apprentices in their firm at the time of our survey, were shown resumes of fictitious secondary-school graduates with an intermediate school degree applying for a fictitious apprentice position.

To create realistic resumes, we used real resumes to set up our fictitious resumes. ${ }^{18}$ Prior to our main survey experiment, we conducted field interviews with HR managers responsible for selecting candidates in six firms located in Munich (also drawn from the ifo Personnel Manager Survey database) to assess whether our fictitious resumes were realistic. Importantly, all interviewed HR managers stated that our skill signals included in the fictitious resumes are relevant criteria at the first stage of the hiring process. We also discussed the values that these signals typically take on in practice, e.g., the common range of values of school grades and college grades. While also receiving feedback on the questionnaire (see Section 5), these expert interviews mainly helped to set up realistic resumes that are appropriate to answer our research questions.

${ }^{16}$ Additional analyses (not shown) reveal that the resume shown on the left-hand side is chosen with the same probability as the resume shown on the right-hand side. Including an indicator for the side on which a CV is shown does not affect our estimates.

${ }^{17}$ HR managers are assigned to this group if their establishment either (i) does not offer apprentice positions, (ii) has a share of at least 25 percent of college-educated employees, or (iii) has a share of at least 5 percent college-educated employees and the majority of apprentices have completed the most academic high-school track (Abitur).

${ }^{18}$ We did not include a cover letter or a photograph on the resume, which is standard in German applications, since HR managers in our study were fully aware that they face fictitious candidates. 


\subsection{The Resumes}

\section{Secondary-School Graduates}

The resumes shown to the HR managers are one-page CVs that contain standard information that would generally be included in job applications in Germany. ${ }^{19}$ Appendix A1 describes all elements of the resumes of secondary-school graduates in detail. Figure A1 shows an example of a resume of a secondary-school graduate and Table A1 lists all possible values of all CV elements.

All fictitious secondary-school graduates obtained an intermediate school degree (Mittlere Reife) after 10 years of schooling. ${ }^{20}$ Because mobility is typically low among individuals with vocational education in Germany, all secondary-school graduates were born and attended school in the state of the HR manager's firm. ${ }^{21}$ Furthermore, at the beginning of the online survey, HR managers are asked whether their firm offers predominantly technical or commercial apprenticeships. Depending on the answer to this question, the resumes include candidates who have completed an internship in the respective field (technical or commercial). To further increase realism, we ensure that HR managers receive female applicants only if the share of female employees in their industry is at least 20 percent. $^{22}$

The resumes include the following specific signals of the three broad domains of skills that we focus on in this study: Cognitive skills of secondary-school graduates are signaled by their final GPA in school, extended IT skills, English proficiency, and proficiency in French or Spanish as a second language. ${ }^{23}$ Social skills are signaled by social volunteering (neighborhood help: youth work, elderly group, and offering German language courses) and by

${ }^{19}$ Firms typically receive many applications for apprenticeship positions. Therefore, in the first stage, HR managers pre-select appropriate candidates based on written applications, which include a cover letter, the resume, and various documents. Subsequently, large firms may conduct written tests and ask applicants to do some trial work, followed by job interviews. About 30 to 40 percent of applicants pass the first stage and only 10 to 15 percent are eventually invited to job interviews (Protsch and Solga 2015).

${ }^{20}$ The German school system tracks students (in almost all states) after four years in primary school into three secondary-school tracks that differ in academic orientation: basic school (Hauptschule), intermediate school (Realschule), and high school (Gymnasium). Basic school is the least academic track and lasts until grade 9 or 10. It is typically followed by an apprenticeship in a firm that includes part-time attendance in a vocational school. Intermediate school usually lasts until grade 10 and is traditionally also followed by such an apprenticeship. High school is the most academic track and lasts until grade 12 or 13 . It is meant to prepare students for college, with the high-school leaving certificate (Abitur) being a precondition for attending college.

${ }^{21}$ Fictitious candidates are born in the capital of the respective state (there are 16 states in Germany), where they have also attended an (existing) intermediate school and completed their internship.

${ }^{22}$ The share of female employees per industry is computed using the statistics of the German Statistical Office from 2015. We distinguish between 62 industries based on the two-digit German Classification of Economic Activity, Version 2003.

${ }^{23}$ Grades in Germany range from 1 (very good) to 6 (failed). For the empirical analysis, we recode all grades (GPAs) such that higher values mean better grades. 
reporting team sports (as opposed to single sports). Maturity is signaled by age, with the older candidate being born in the calendar year before the younger candidate (but, given the year of school graduation, from the same "regular" school birth cohort), and by having conducted a long internship (four weeks as opposed to two weeks). ${ }^{24}$

As HR managers have to select exactly one of the two candidates, we design resumes such that one resume does not "dominate" the other resume within a CV pair to avoid obvious choices. To this end, we introduce a negative correlation between the school GPA (likely an important skill signal) and the other skill signals in the CV. This means that the CV with the better GPA gets worse other skill signals, such as lower language and IT skills (see Appendix A1 for details).

Finally, as the effects of innate characteristics have already been studied extensively in the literature, we intentionally keep these characteristics fixed within the choice sets in our experimental design. That is, we keep gender fixed within CV pairs and use only fictitious candidates with German nationality and standard German-sounding names (see Appendix A1 for details).

\section{College Graduates}

The setup of resumes of college graduates is similar to those of secondary-school graduates, with only few obvious differences. Appendix A2 describes the elements of the resumes of college graduates in detail. Table A2 lists all values of all CV elements and Figure A2 presents a sample resume for college graduates.

All fictitious college graduates completed upper-track high school (Gymnasium) after 12 years of schooling and subsequently obtained a four-year Bachelor's degree in business administration at a public German university. We chose business administration since this is by far the most common college major in Germany, with 15 percent of all university students being enrolled in business administration during the academic year 2015/16 (Federal Statistical Office 2016). Because business administration is so pervasive, most firms likely hire college graduates with this major. This choice seems particularly appropriate for our context as we do not send applications to actual job advertisements but rather ask HR managers to choose the better fictitious applicant in a setting where they have to fill a universal trainee position in their firm with a college graduate with a business administration degree. We use five top-ranked

\footnotetext{
${ }^{24}$ While these are short periods, it is uncommon for a 16- or 17-year-old secondary-school graduate to have more labor-market experience. Importantly, whereas a two-week internship may signal a compulsory internship during the school year, a four-week internship tends to signal a voluntary labor-market experience obtained during vacations.
} 
universities and five lower-ranked universities to investigate whether the impact of college GPA varies with college quality (the category, e.g., top-ranked university, is held constant within a CV pair; see Appendix A2 for details).

Cognitive skills of college graduates are signaled by their college GPA, the most recent productivity signal obtained just before entering the labor market. Further signals of cognitive skills again include extended IT skills, English proficiency (measured as $0=$ basic, $1=$ very good, and 2 = fluent), and proficiency in French or Spanish as a second language. Social skills are signaled by volunteering activities that involve intensive interactions with other people (neighborhood help or mobile care services) as opposed to volunteering activities that involve only limited social interactions (preservation of monuments or online IT work and translations for the United Nations). Again, social skills are also signaled by engaging in team sports as opposed to single sports. As for secondary-school graduates, maturity is signaled by age, with the older candidate being born in the calendar year before the younger candidate (but, given the year of high-school graduation, from the same "regular" school birth cohort). Maturity is additionally signaled by having completed a long internship (three or five months as opposed to only one month). In this context, we interpret high-school GPA as another signal of maturity as, conditional on college GPA, it is more likely to be perceived as a measure of effort during adolescence rather than a signal for cognitive skills.

In contrast to secondary-school graduates, who apply for an apprenticeship position in their region, college graduates are geographically more mobile. While they attended a high school in their city of birth (using schools that actually exist), college graduates are completely mobile with respect to both the college location and the location of the HR manager's firm.

Each element on the resume is randomized independently of all other CV elements, except for one restriction on GPAs: while the first three GPAs within a CV pair (there are two high-school GPAs and two college GPAs) are randomized independently of each other, the fourth GPA, randomized last, is restricted such that no resume contains both a better high-school GPA and a better college GPA. We impose this restriction since HR managers may select the resume that dominates the other resume with two better GPAs. Finally, as for the resumes of the secondary-school graduates, we keep gender constant within CV pairs and use only candidates with German nationality and German-sounding names.

\subsection{Descriptive Statistics}

We sent the online survey to HR managers in 1,496 firms (one HR manager per firm), of whom 579 HR managers participated. 307 respondents participated in the secondary-school- 
graduate sample and 272 in the college-graduate sample. Given that each HR manager was exposed to two pairs of resumes, we have a total of 1,158 decisions and 2,316 resumes.

Table 1 provides summary statistics of the resume characteristics for the secondaryschool-graduate sample and Table 2 for the college-graduate sample. By construction, the mean of our outcome variable - the job interview invitation - is 0.5. The average school GPA (GPAs are recoded as "4 minus actual grade” such that higher values mean better grades) is 1.46 for secondary-school graduates and 1.68 for college graduates; average college GPA is 1.67. There are slightly more male applicants in the secondary-school-graduate sample (56.8 percent), which is due to the fact that female applicants are only presented to HR managers in industries with more than 20 percent of female employees. ${ }^{25}$

The distribution of firms in the ifo Personnel Manager Survey is representative for firms in Germany. As shown in Table A3 in the appendix, HR managers (and their firms) who participate in our study do not differ significantly from non-respondents of the ifo Personnel Manager Survey database in terms of location, industry, number of employees, and share of females in the industry.

\subsection{Empirical Model}

The independent randomization of the different skill signals provides us with identification of their causal effects on being invited for a job interview. We estimate the effects in a first-differenced model, treating a resume pair as the unit of observation. Accordingly, the dependent variable equals one if the resume on the left-hand side was selected and equals minus one if the resume on the right-hand side was selected. Similarly, all explanatory variables are constructed as first differences, i.e., the characteristic of the left-hand side resume minus the characteristic of the right-hand side resume. We hence estimate the following OLS specification:

$$
\Delta y_{i j}=\beta_{0}+\beta_{1}{ }^{\prime} \Delta S_{i j}+\varepsilon_{i j}
$$

where $\Delta y_{i j}$ is the outcome for CV pair $i(i=1,2)$ of HR manager $j . \Delta S_{i j}$ is a vector of $\mathrm{CV}$-pair-specific differences in skill signals, and $\varepsilon_{i j}$ is an error term. In some specifications, we additionally include industry fixed effects and even HR manager fixed effects, thus exploiting only variation in the choices within HR managers across the two CV pairs. Our parameters of

\footnotetext{
${ }^{25}$ In contrast, the lower share of male applicants in the college-graduate sample arises due to chance in the randomization procedure.
} 
interest that capture the impact of the skill signals are given by the vector $\beta_{1}$. Throughout, we cluster standard errors at the level of the HR manager.

Note that the magnitudes of the estimated effects of the skill signals do not have a straightforward interpretation in our setting because HR managers are forced to choose exactly one of the two applicants in each CV pair. This likely overemphasizes the importance of the skill signals since HR managers might choose both applicants or none when facing real applications, at least in the first stage of the application process. Therefore, we prefer to interpret relative effect sizes, comparing the importance of two different skill signals.

To investigate heterogeneities in the effects of skill signals by HR managers' characteristics, we estimate models with interaction terms between the two:

$$
\Delta y_{i j}=\beta_{0}+\beta_{1}^{\prime} \Delta S_{i j}+\beta_{2}^{\prime} C_{j} \Delta S_{i j}+\varepsilon_{i j}
$$

where $C_{j}$ is a characteristic of HR manager $j$. In particular, we explore two dimensions of potential heterogeneity in the valuation of skill signals by HR managers. First, we study whether skill signal effects vary with HR managers' characteristics such as their age, gender, position and responsibility in the firm, and the size of their firm. Second, we test the consistency between HR managers' observed choices and the preferences that they express for a particular skill signal in the subsequent questionnaire.

\section{The Impact of Skill Signals on Job-Interview Invitations}

We start by presenting the baseline results of the impact of signals of cognitive skills, social skills, and maturity on job-interview invitations for secondary-school graduates and college graduates. In the next section, we turn to effect heterogeneities for different HR managers.

\subsection{Baseline Results for Secondary-School Graduates}

Table 3 reports the baseline results of the choice experiment in the secondary-schoolgraduate sample. The baseline specification indicates significant effects of skill signals in each of the three domains - cognitive skills, social skills, and maturity (column 1). Results hardly change when industry fixed effects are added to the first-differenced model (column 2).

Signals of cognitive skills strongly affect the invitation decision. In the given setting, an improvement in school GPA by one grade level increases the probability of being invited for a job interview, ceteris paribus, by 22 percentage points. The point estimates do not differ 
significantly between female and male applicants (columns 3 and 4), although the coefficient is slightly smaller and less precisely estimated in the female sample. We tested for non-linearity in the effects of school GPA by adding two interaction terms: school GPA interacted with an indicator for whether both school GPAs in the CV pair are equal or better than 2.3 (a good GPA) and school GPA interacted with an indicator for whether both school GPAs in the CV pair or equal or worse than 2.7 (a mediocre GPA). The coefficients on both interaction terms are insignificant (not shown), indicating that the impact of school GPA is rather linear. ${ }^{26}$

Extended IT skills also improve the odds of being invited to a job interview. This effect is more pronounced for female applicants, which might reflect gender stereotypes among HR managers that males in general have reasonably IT skills, so that females' returns to these skills are higher. Foreign language skills, another dimension of cognitive skills, seem to be less important in case of an apprenticeship application. The effect of being fluent (as opposed to basic) in English is marginally significant, whereas having a second foreign language (either French or Spanish) does not have a significant effect.

Applicants who signal social skills by social volunteering - that is, they report doing neighborhood help such as youth work, elderly group, and offering German language courses have a 37 percentage points higher probability to be invited for a job interview in our setting than identical applicants who have not volunteered. The effect size is almost equivalent to improving school GPA by two grade levels and is similar for females and males. This indicates strong importance of signaling social skills and commitment for young applicants who enter the labor market directly out of school. A potential second signal of social skills is whether an applicant participates in team sports such as football and basketball as opposed to single sports such as swimming and cycling. This signal, however, does not affect the interview invitation among applicants for apprenticeship positions. This may reflect that the social skill component here is dominated by social volunteering and that 17-year-olds commonly play team sports which may not make it a very good predictor for actual social skills at this age.

Concerning maturity, HR managers significantly prefer older applicants for apprenticeship positions. While all fictitious applicants are 17 years old and born within the same "regular" birth cohort (given the school graduation year), applicants born in calendar year 1998 are more likely, ceteris paribus, to get chosen than applicants born in 1999. This effect is entirely driven by male applicants for apprenticeship positions, the only significant gender difference in the skill-signal effects. Boys may generally be perceived as more immature than girls during

${ }^{26}$ Similarly, we do not find evidence of non-linearity in the form of an additional effect of having a grade that starts with a one (indicating top grades in Germany) when added to the linear grade effect (not shown). 
adolescence (another form of gender stereotype), so that being slightly older is a relevant signal of maturity for them. By contrast, we do not find a significant effect of having completed a longer internship - four weeks rather than two weeks - in the secondary-school-graduate sample.

As each HR manager receives two pairs of resumes and, thus, makes two choices, we can additionally restrict the analysis to exploit only variation in decisions within HR managers. With HR manager fixed effects taking out most of the variation, estimates become imprecise (with standard errors tending to double) and only the effect of social volunteering retains statistical significance at conventional levels (column 5). However, point estimates remain very similar to the baseline model.

\subsection{Baseline Results for College Graduates}

Table 4 presents baseline results of the choice experiment in the college-graduate sample. Again, we find significant effects of skill signals in each of the three skill domains. However, the specific signals that affect job-interview invitations for college graduates partly differ from the specific signals relevant for secondary-school graduates. ${ }^{27}$

Results show that college grades as a signal of cognitive skills are an important determinant in the first stage of the hiring decision of HR managers. A better college GPA significantly increases the probability of being invited to a job interview for both females and males. In the given setting, a better college GPA by one grade level increases the likelihood of a job-interview invitation by 38 percentage points. Again, we do not find evidence of non-linearity in the effects of GPA in the college setting (not shown).

Results for other cognitive-skill domains are mixed. Extended IT skills and English proficiency do not affect the interview decision in the college-graduate sample. One possible explanation is that firms expect that German college graduates have reasonably decent IT skills and English proficiency anyways. However, proficiency in a second foreign language (French or Spanish) does improve the probability of an interview invitation. This effect is entirely driven by female college graduates, whereas no such effect is observed for males, possibly reflecting gender stereotyping among HR managers. The effect is very similar for whether the second foreign language is French or Spanish (not shown).

\footnotetext{
${ }^{27}$ We replicated all results from Tables 3 and 4 by weighting HR managers with the (log) firm size to account for the relative overrepresentation of small firms in the German economy. These results are very similar to the unweighted results (not shown).
} 
Signals of social skills also matter for the employability of college graduates, although to a substantially lesser extent than the signals of cognitive skills. Among females, volunteering work that is characterized by intensive social interactions (such as neighborhood help or mobile care services) is an advantage over volunteering work that involves less social interactions (such as monument preservation or online office work for the UN). No such effect is found for males. Note that the treatment here is different from the secondary-school-graduate sample, where applicants do or do not report volunteering work, whereas all college graduates report some sort of volunteering, only that its intensity of social interactions differs.

Interestingly, participation in team sports such as football and basketball, as opposed to single sports such as swimming and cycling, increases the probability of a job interview in the college-graduate sample. This contrasts with the lack of an effect in the secondary-school sample. Potentially, at the age of 17, the type of sport that an applicant does may be conceived as being primarily determined by family and friends rather than being a personal choice, so that it does not signal well for the applicant's social skills. By contrast, at the age of 24 in the college-graduate sample, the type of sports that a person decides to (continue to) participate in may be more likely perceived as a personal choice and thus as a better signal of social skills. In addition, HR managers may be wary of strategic behavior among applicants who have reached the stage of finishing college. This could account for the fact that reporting social volunteering work has a much smaller effect in the college sample than in the secondary-school sample (besides reflecting a somewhat weaker variation in the signal), whereas it is the other way around for reporting team sports. Knowing that firms value social volunteering (Baert and Vujić 2016), even persons with limited social skills may do some voluntary social work only to have the signal. With limited credibility of volunteering as a signal of actual social skills, HR managers may revert to the type of sports as an alternative signal that is less obvious and may thus be less subject to strategic manipulation.

Signals of maturity also seem to play some role in the hiring of college graduates, but again to a lesser extent than cognitive skills. In particular, a longer internship - three or five months as opposed to one month - increases the probability of being invited to a job interview. ${ }^{28}$ In contrast to secondary-school graduates, we do not find an advantage for older applicants, presumably because small age differences are less relevant for applicants aged 24 than for applicants during their adolescence (aged 17 in the secondary-school-graduate sample). For male college-graduate applicants, we find a significant effect of a better high-school GPA.

\footnotetext{
${ }^{28}$ There are two separate treatments, either three months of internship or five months of internship. We do not find a significant difference between the two treatment effects, so we combine them into one indicator.
} 
Holding constant college GPA, we interpret this as a signal that the applicant focused on school work already during adolescence. ${ }^{29}$ No such effect is found for female college-graduate applicants. This may reflect the same gender stereotype as in the secondary-school-graduate sample: boys are perceived as more immature than girls during adolescence, and therefore have higher returns to signals of maturity. ${ }^{30}$

While less precisely estimated, the order of magnitude of the point estimates and the pattern of results are again confirmed in the specification with HR manager fixed effects (column 5). In the college-graduate sample, the effects of college GPA, team sports, and internship duration retain statistical significance at conventional levels even though standard errors with HR manager fixed effects roughly double.

In sum, signals in all three domains - cognitive skills, social skills, and maturity - have a causal impact on the decisions of HR managers whom to invite for a job interview both among secondary-school graduates and among college graduates. In general, cognitive skills as signaled by school GPA for secondary-school graduates and college GPA for college graduates play a consistently important role. Among college graduates, cognitive skills tend to be relatively more relevant than social skills, whereas social skills seem to be more relevant for young school graduates applying for an apprenticeship. Signals of maturity also tend to be more important for young job applicants in their adolescence, with effects being restricted to boys. In contrast, IT skills tend to be more important for female secondary-school graduates, possibly because of common gender stereotypes that boys have an affinity to computers. Overall, the observed effect heterogeneities across entry ages and genders appear consistent with differences in the relevance, expectedness, and credibility of specific signals in different settings. $^{31}$

${ }^{29}$ Additionally controlling for whether the GPA has improved from school to college does not change the coefficient on high-school GPA and slightly increases the coefficient on college GPA (not shown).

30 Some German states have a tradition of having central exit exams at the end of high school, whereas other states do not. All but one state have introduced central exams in recent years, but one might argue that the different traditions still lead to a higher information value of grades in states where central exams have ascertained greater comparability for a long time (Schwerdt and Woessmann 2017). Indeed, when we interact the high-school GPA with an indicator of whether the individual's state of schooling traditionally had central exit exams, we find a positive coefficient on the interaction term that reaches marginal significance for females, but not for males (albeit equal in size; not shown).

${ }^{31}$ While the setup of our experiment was not designed for deeper investigation of the importance of complementarities among different skills or different packages of skills, we also experimented with adding interaction terms between different skill signals to our baseline model (not shown). There are virtually no significant interaction effects among the different randomized skill signals, possibly due to limited statistical power in these models. In particular, we do not find significant interactions between GPAs and social skills. Similarly, there is no consistent pattern of effect heterogeneities by the four high-school types used on the college-graduate resumes or by whether the college is top-ranked or not. 


\section{Heterogeneous Effects for Different HR Managers}

In this section, we turn to effect heterogeneities with respect to $\mathrm{HR}$ manager characteristics. Furthermore, we investigate whether decisions in the choice experiment are consistent with HR managers' answers to survey questions regarding the importance of various skill signals of applicants in their firm.

\subsection{Heterogeneity by HR Manager Characteristics}

In contrast to most existing CV studies, we have information about the characteristics of the HR managers who make the decisions in our setting. After the choice experiments, we provide the HR managers with a short survey questionnaire that includes questions on their personal characteristics and on the importance they assign to different skill signals in actual applications to their firm (see Appendix A3 for details). The information on HR managers' personal characteristics includes age, gender, educational attainment, whether they are responsible for hiring decisions in their firm, whether they are the managing director of the firm (more likely in smaller firms), and how many job interviews they have conducted during the past 12 months. This information allows us to investigate whether the effects of the different skill signals differ across different types of HR managers.

Table 5 provides summary statistics of HR managers' characteristics and firm characteristics, separately for the secondary-school-graduate sample and the college-graduate sample. In both samples, HR managers are on average 50 years old, and about two thirds are male. HR managers in the secondary-school-graduate sample are more likely to be managing directors of their firms, presumably because these firms tend to be smaller than those in the college sample. Most HR managers (87-88 percent) are responsible for the actual hiring decisions in their firm. Overall, HR managers are similarly divided between the three types of professional degrees - vocational education, university of applied sciences, and university - in the two samples. Firms in the secondary-school-graduate sample, all of which employ apprentices, are more likely to be in the manufacturing sector, whereas firms in the college-graduate sample are more likely to be in the real estate sector. Furthermore, firms in the secondary- school-graduate sample are more likely to be in industries where the share of women is below 20 percent. This is likely due to the fact that many apprenticeship positions are technical jobs.

Tables 6 and 7 report estimated coefficients on interaction terms between the various skill signals (indicated in the first column) and selected characteristics of the HR managers and 
firms (indicated in the column headers) for the secondary-school-graduate and the college-graduate sample, respectively. Each cell stems from a separate regression.

For apprenticeship positions, we find substantial effect heterogeneity with respect to HR manager characteristics (Table 6). Older HR managers (median split at age 51) put less weight on school grades, but more weight on IT skills. Older managers also appreciate social volunteering more, but consider team sports to be less important for the decision whom to invite for a job interview. These differences between young and old HR managers might indicate that older HR managers experienced that school grades predict the workplace performance of apprentices less well than signals of specific abilities such as IT skills. Similarly, experienced HR managers might have experienced that social volunteering is indeed a good signal for social skills that are important on the labor market. Interestingly, the focus of HR managers who are also the managing directors of their firm goes in the same direction as that of older HR managers, partly reflecting that the majority of managing directors (59.5 percent) are also in the subgroup of older HR managers. Furthermore, managing directors also place more weight on work experience through long internships than HR managers who are not managing directors. The latter is also true for HR managers who are responsible for hiring decisions in their firm.

We also find substantial, and intuitive, differences between apprenticeship positions in the technical sector and in the commercial area. Concerning signals of cognitive skills, the priorities of HR managers in the technical sector are more strongly focused on school GPA and less on specific skills in IT and second foreign languages, which might be particularly relevant for apprenticeship positions in the commercial area. Similarly, social volunteering is more important in the commercial area, likely because social skills are more relevant in commercial jobs than in technical jobs. In line with this finding, longer internship duration as a signal of maturity is also more important for HR managers in the commercial area than in the technical sector. By contrast, effects of the different skill signals in the secondary-school-graduate sample hardly differ between female and male HR manager, and they do not vary significantly with firm size.

Overall, there is less effect heterogeneity with respect to HR manager characteristics in the college-graduate sample (Table 7). Interestingly, HR managers in larger firms place more weight on the college GPA, which may reflect a more streamlined and automated screening process in larger firms with a particular focus on formal signals or with applicants having to pass a specific GPA threshold. Easy verifiability of signals may thus be particularly important for large firms in the first hiring stage. Older HR managers, male HR managers, and those with 
hiring responsibility place more weight on proficiency in a second foreign language. Internship duration seems less important for managing directors and HR managers with hiring responsibility. HR managers who obtained an apprenticeship degree care less about highschool GPA than HR managers with a college degree; HR managers with a technical college degree put less weight on college GPA and more on social skills.

\subsection{Consistency with Stated Priorities in Survey Questions}

At the end of the questionnaire, HR managers also indicate their priorities for various skill signals of actual applicants applying for jobs in their firm. Table 8 shows that 67 percent of HR managers in the secondary-school-graduate sample report that school GPAs are either "rather important” or “very important” (as opposed to “rather unimportant” or “very unimportant”). An even larger share of HR managers states that school grades in specific main subjects are important: 89 percent in math and 81 percent in German. IT skills are considered important by 86 percent of HR managers, language skills by 66 percent, and professional experience through internships by 74 percent. In the college-graduate sample, 47 percent of HR managers view high-school GPA as important and 81 percent college GPA, the more recently acquired skill signal. The shares of HR managers who view IT skills (96 percent), language skills (83 percent), and professional experience through internships (94 percent) as important are all higher in the college-graduate sample than in the secondary-school-graduate sample. The only dimension without a significant difference between the two samples is hobbies (47-48 percent).

The priorities reported by HR managers in the questionnaire allow us to investigate whether answers to survey questions are consistent with their choices between the fictitious applicants in the choice experiment. This yields insights into whether HR managers' answers in survey questionnaires are in line with their decisions when comparing entire resumes of applicants. To investigate this question, we add to our baseline model an interaction term between a skill signal in our fictitious resumes and the degree of importance that the HR manager assigns to that specific skill signal in the questionnaire (using the original four-point scale). We estimate models with interaction terms separately for each skill signal that is included both in the questionnaire and in the fictitious resumes.

Among HR managers in the secondary-school-graduate sample, all interaction terms are positive and statistically significant (Table 9). This implies that HR managers who report in the questionnaire that a certain skill signal is important do indeed put more weight on that signal when choosing between resumes. This is the case for school GPA, IT skills, language proficiency (English and second foreign language), and internship duration. 
Similar positive interactions are found among HR managers in the college-graduate sample, with the interactions with college GPA, IT skills, and English language proficiency reaching statistical significance at conventional levels (Table 10). The results again indicate that choices are consistent with self-reported priorities in the questionnaire. Interestingly, statistical significance is observed for the three signals of cognitive skills, which is the most important domain of signals among college graduates, whereas the signals of maturity (high-school GPA and internship duration), which are in general less important for decisions among college graduates, do not capture statistical significance.

\section{Conclusion}

We conduct a randomized CV study among HR managers to investigate how acquired signals of a broad range of cognitive skills, social skills, and maturity are valued by employers. We find evidence that signals in each of the three domains increase the probability of being invited for a job interview. Given our experimental design, these are separate and independent effects of signals in the different skill domains, with little evidence of strong complementarities between the different domains. The results indicate that skills in all three domains matter on the labor market, that applicants can effectively signal these skills to employers before career start with information contained on their CVs, and that associations of labor-market outcomes with skill indicators such as school or college grades in observational data do in fact have a causal interpretation in the sense that employers observe and react to them during the application stage.

Furthermore, the importance of the specific signals differs depending on the respective relevance, stereotypical expectedness, and credibility of the signal in different contexts. Important effect heterogeneities exist, among others, between secondary-school graduates applying for an apprentice position and college graduates. While signals of cognitive skills (particularly college GPA) seem to be more important than signals of social skills and maturity among college graduates, the same is not true for secondary-school graduates. School GPA of secondary-school graduates and college GPA of college graduates - signals of cognitive skills - are important for both genders, but other signals matter more for one gender than the other: While IT and second language skills - and, to a lesser extent, social skills - are particularly relevant for females, signals of maturity are particularly relevant for males. These differences might reflect gender stereotypes, with stronger effects for the gender for which the skill is less expected. While social volunteering is a strong signal of social skills among secondary-school graduates, social skills are more effectively signaled by engaging in team sports among college 
graduates, consistent with reduced credibility of social volunteering as a signal of actual social skills due to potential strategic behavior at older ages.

We also find differences in the impact of skill signals across different groups of HR managers. For secondary-school graduates, older HR managers and managing directors put less weight on school GPA and more weight on IT skills, social volunteering, and internship duration. Among college graduates, HR managers in larger firms place more weight on college GPA than those in smaller firms, which might be due to more standardized procedures of hiring applicants in larger firms that attach more importance to easily verifiable skill signals. Using a questionnaire that asks HR managers to indicate their priorities of skill signals of actual applicants applying for jobs in their firm, we find that the decisions in the choice experiments are consistent with HR managers' self-reported hiring priorities. Together, the effect heterogeneities by entry age, gender, and HR managers reveal important aspects about how signals of skills are processed and utilized in the labor market. 


\section{References}

Almlund, Mathilde, Angela Duckworth, James. J. Heckman, and Tim Kautz (2011). Personality Psychology and Economics. In Handbook of the Economics of Education, Volume 3, ed. Eric A. Hanushek, Steve Machin, and Ludger Woessmann, pp. 1-181. Amsterdam: North-Holland.

Altonji, Joseph G., and Charles R. Pierret (2001). Employer Learning and Statistical Discrimination. Quarterly Journal of Economics 116 (1), 313-350.

Arceo-Gomez, Eva O., and Raymundo M. Campos-Vazquez (2014). Race and Marriage in the Labor Market: A Discrimination Correspondence Study in a Developing Country. American Economic Review 104 (5), 376-380.

Arcidiacono, Peter, Patrick Bayer, and Aurel Hizmo (2010). Beyond Signaling and Human Capital: Education and the Revelation of Ability. American Economic Journal: Applied Economics 2 (4), 76-104.

Arrow, Kenneth. J. (1973). Higher Education as a Filter. Journal of Public Economics 2 (3), 193-216.

Baert, Stijn, and Sunčica Vujić (2016). Does It Pay to Care? Prosocial Engagement and Employment Opportunities. IZA Discussion Paper 9649. Bonn: Institute for the Study of Labor.

Bertrand, Marianne, and Esther Duflo (2016). Field Experiments on Discrimination. NBER Working Paper 22014. Cambridge, MA: National Bureau of Economic Research.

Bertrand, Marianne, and Sendhil Mullainathan (2004). Are Emily and Greg More Employable Than Lakisha and Jamal? A Field Experiment on Labor Market Discrimination. American Economic Review 94 (4), 991-1013.

Bishop, John H. (1989). Is the Test Score Decline Responsible for the Productivity Growth Decline? American Economic Review 79 (1), 178-197.

Booth, Alison, and Andrew Leigh (2010). Do Employers Discriminate by Gender? A Field Experiment in Female-dominated Occupations. Economics Letters 107 (2), 236-238.

Borghans, Lex, Angela Lee Duckworth, James J. Heckman, and Bas ter Weel (2008). The Economics and Psychology of Personality Traits. Journal of Human Resources 43 (4), 972-1059.

Bowles, Samuel, Herbert Gintis, and Melissa Osborne (2001). The Determinants of Earnings: A Behavioral Approach. Journal of Economic Literature 39 (4), 1137-1176.

Card, David (1999). The Causal Effect of Education on Earnings. In Handbook of Labor Economics, Volume 3a, ed. Orley Ashenfelter and David Card, pp. 1801-1863. Amsterdam: North-Holland.

Chetty, Raj, John N. Friedman, Nathaniel Hilger, Emmanuel Saez, Diane Whitmore Schanzenbach, and Danny Yagan (2011). How Does Your Kindergarten Classroom Affect Your Earnings? Evidence from Project STAR. Quarterly Journal of Economics 126 (4),1593-1660.

Clark, Damon, and Paco Martorell (2014). The Signaling Value of a High School Diploma. Journal of Political Economy 12 (2), 282-318.

Deming, David J. (2017). The Growing Importance of Social Skills in the Labor Market. Quarterly Journal of Economics 132 (4), 1593-1640. 
Deming, David J., Noam Yuchtman, Amira Abulafi, Claudia Goldin, and Lawrence F. Katz (2016). The Value of Postsecondary Credentials in the Labor Market: An Experimental Study. American Economic Review 106 (3), 778-806.

Englmaier, Florian, and Georg Gebhardt (2016). Social Dilemmas in the Laboratory and in the Field. Journal of Economic Behavior and Organization 128, 85-96.

Falk, Armin, Rafael Lalive, Josef Zweimüller (2005). The Success of Job Applications: A New Approach to Program Evaluation. Labour Economics 12 (6): 739-748.

Federal Statistical Office (2016). Studierende an Hochschulen, Fachserie 11, Reihe 4.1, WS 2015/2016.

Hanushek, Eric A., Guido Schwerdt, Simon Wiederhold, and Ludger Woessmann (2015). Returns to Skills around the World: Evidence from PIAAC. European Economic Review 73, 103-130.

Hanushek, Eric A., Guido Schwerdt, Simon Wiederhold, and Ludger Woessmann (2017). Coping with Change: International Differences in the Returns to Skills. Economics Letters 154, 15-19.

Hanushek, Eric A. and Ludger Woessmann (2008). The Role of Cognitive Skills in Economic Development. Journal of Economic Literature 46 (3), 607-668.

Heckman James J., John E. Humphries, and Nicholas S. Mader (2011). The GED. In Handbook of the Economics of Education, Volume 3, ed. Eric A. Hanushek, Steve Machin, and Ludger Woessmann, pp. 423-484. Amsterdam: North-Holland.

Heckman, James J., Lance J. Lochner, and Petra E. Todd (2006). Earnings Functions, Rates of Return and Treatment Effects: The Mincer Equation and Beyond. In Handbook of the Economics of Education, Volume 1, ed. Eric A. Hanushek and Finis Welch, pp. 307-458. Amsterdam: North-Holland.

Heckman, James. J., Jora Stixrud, and Sergio Urzua (2006). The Effects of Cognitive and Noncognitive Abilities on Labor Market Outcomes and Social Behavior. Journal of Labor Economics 24 (3), 441-482.

Heineck, Guido, and Silke Anger (2010). The Returns to Cognitive Abilities and Personality Traits in Germany. Labour Economics 17 (3), 535-546.

Heinz, Matthias, and Heiner Schumacher (2017). Signaling Cooperation. European Economic Review 98, 199-216.

Humburg, Martin, and Rolf van der Velden (2015). Skills and the Graduate Recruitment Process: Evidence from Two Discrete Choice Experiments. Economics of Education Review 49, 24-41.

Koedel, Cory, and Eric Tyhurst (2012). Math Skills and Labor-Market Outcomes: Evidence from a Resume-based Field Experiment. Economics of Education Review 31 (1), 131-140.

Kübler, Dorothea, and Julia Schmid (2015). Take Your Time to Grow: A Field Experiment on the Hiring of Youths in Germany. WZB Discussion Paper SP II 2015-205. Berlin: Berlin Social Science Center (WZB).

Lang, Kevin, and Michael Manove (2011). Education and Labor Market Discrimination. American Economic Review 101 (4), 1467-1496.

Lindqvist, Erik, and Roine Vestman (2011). The Labor Market Returns to Cognitive and Noncognitive Ability: Evidence from the Swedish Enlistment. American Economic Journal: Applied Economics 3 (1), 101-128. 
MacLeod, W. Bentley, Evan Riehl, Juan E. Saavedra, and Miguel Urquiola (2017). The Big Sort: College Reputation and Labor Market Outcomes. American Economic Journal: Applied Economics 9 (3), 223-261.

Mueller, Gerrit, and Erik Plug (2006). Estimating the Effects of Personality on Male and Female Earnings. Industrial and Labor Relations Review 60 (1), 3-22.

Mulligan, Casey B. (1999). Galton versus the Human Capital Approach to Inheritance. Journal of Political Economy 107 (6), 184-224.

Murnane, Richard J., John B. Willett, and Frank Levy (1995). The Growing Importance of Cognitive Skills in Wage Determination. Review of Economics and Statistics 77 (2), 251-266.

Neal, Derek, and William R. Johnson (1996). The Role of Premarket Factors in Black-White Wage Differences, Journal of Political Economy 104 (5), 869-895.

Neumark, David (2016). Experimental Research on Labor Market Discrimination. NBER Working Paper 22022. Cambridge, MA: National Bureau of Economic Research.

Oreopoulos, Philip (2011). Why Do Skilled Immigrants Struggle in the Labor Market? A Field Experiment with Thirteen Thousand Resumes. American Economic Journal: Economic Policy 3 (4), 148-171.

Protsch, Paula, and Heike Solga (2015). How Employers Use Signals of Cognitive and Noncognitive Skills at Labour Market Entry: Insights from Field Experiments. European Sociological Review 31 (5), 521-532.

Riach, Peter A. (2015). A Field Experiment Investigating Age Discrimination in Four European Labour Markets. International Review of Applied Economics 29 (5), 608-661.

Rich, Judith (2014). What Do Field Experiments of Discrimination in Markets Tell Us? A Meta Analysis of Studies Conducted since 2000. IZA Discussion Paper 8584. Bonn: Institute for the Study of Labor.

Riley, John G. (2001). Silver Signals: Twenty-Five Years of Screening and Signaling. Journal of Economic Literature 39 (2), 432-478.

Roemer, John E. (1998). Equality of Opportunity. Cambridge, MA: Harvard University Press.

Ruffle, Bradley J., and Ze'ev Shtudiner (2015). Are Good-Looking People More Employable? Management Science 61 (8), 1760-1776.

Schwerdt, Guido, and Ludger Woessmann (2017). The Information Value of Central School Exams. Economics of Education Review 56, 65-79.

Spence, Michael (1973). Job Market Signaling. Quarterly Journal of Economics 87 (3), 355-374.

Stiglitz, Joseph E. (1975). The Theory of "Screening," Education, and the Distribution of Income. American Economic Review 65 (3), 283-300.

Tyler, John H., Richard Murnane, and John Willett (2000). Estimating the Labor Market Signaling Value of the GED. Quarterly Journal of Economics 115 (2), 431-468.

Weinberger, Catherine J. (2014). The Increasing Complementarity between Cognitive and Social Skills. Review of Economics and Statistics 96 (4), 849-861.

Weiss, Andrew (1995). Human Capital vs. Signalling Explanations of Wages. Journal of Economic Perspectives 9 (4), 133-154. 


\section{Appendix A1: Resumes of Secondary-School Graduates}

Each secondary-school graduate applying for an apprenticeship position is represented by a one-page CV. Figure A1 shows an example CV of a secondary-school graduate. Table A1 lists all possible values of all $\mathrm{CV}$ elements that are randomly attributed to the secondary-school-graduate resumes. Elements marked with a star - gender and apprenticeship area (commercial or technical) - do not vary within a CV pair shown to an HR manager. The other elements - name, date of birth, school GPA, internship duration, English proficiency, $2^{\text {nd }}$ foreign language, IT skills, voluntary work, and sports - vary randomly within CV pairs.

We use five different first names for each gender and five different last names. The last names are the most common family names in Germany, while the first names are among the ten most common names of boys and girls of the birth cohort of the fictitious candidates (1998/1999). ${ }^{32}$ Table A4 indicates that HR managers do not strongly prefer specific first names or specific family names. Invitation rates for the job interview differ statistically significantly from 0.5 (at the 5 percent level) in only two of 30 cases. Candidates are born within a four-month period between 15 November 1998 and 10 March 1999 in the capital of the respective state in which the firm is located.

Grades in Germany, both in school and in college, range from 1 (very good) to 6 (failed). A grade of 4 (adequate) is typically the passing grade and GPAs typically involve decimal places. The school GPAs in our resumes range from 1.3 to 3.3, that is, between very good and satisfactory. Each resume includes two sports disciplines, either two team sports or two single sports.

The secondary-school graduates do their internships either in a "technical" or “commercial” job at a local craft or retail company. Technical internships differ across gender and involve, e.g., carpenter for males and hairdresser for females. Commercial internships are the same for both gender and include, e.g., positions in banks or supermarkets.

To obtain a negative correlation between the school GPA and the other skill signals on the resume, we construct a point index for the other skill signals, with each skill signal receiving 1 point if the signal is positive (and 0 otherwise). In particular, the following signals receive 1 point: fluent English proficiency (vs. basic), basic French or Spanish proficiency (vs. no second foreign language), extended IT skills (Microsoft Office plus HTML plus Dreamweaver vs. only Microsoft Office), social volunteering (vs. no volunteering), and four weeks of

\footnotetext{
32 Family names are chosen from the ten most common family names in Germany according to Wikipedia (http://de.wikipedia.org/wiki/Liste_der_h\%C3\%A4ufigsten_Familiennamen_in_Deutschland). First names are taken from the German "popular first names” database (http://www.beliebte-vornamen.de/jahrgang/j1998).
} 
internship (vs. two weeks). Within each CV pair, the resume with the worse school GPA includes other skill signals with an index that is 2, 3, or 4 points higher.

\section{Appendix A2: Resumes of College Graduates}

Each college graduate applying for a business trainee position is represented by a one-page $\mathrm{CV}$. Figure A2 shows an example CV of a college graduate. Table A2 lists all possible values of all CV elements that are randomly attributed to the college-graduate resumes. Elements marked with a star - gender, type of secondary school, college type, and business area of the internship - do not vary within a CV pair shown to an HR manager. The other elements - name, date of birth, place of birth, high-school GPA, college GPA, internship firm and duration, English proficiency, $2^{\text {nd }}$ foreign language, IT skills, volunteering, and sports - vary randomly within CV pairs.

College-graduate resumes have the same five first names and five last names as the secondary-school graduates. The first names are again among the ten most common names in the year the candidates were born. Candidates are born within a four-month period between 15 November 1991 and 10 March 1992 in the capital in one of six states.

The applicants went to one of three high-school types, which are held constant within CV pairs: a regular high school (Gymnasium), a private catholic school, or a comprehensive school. All schools in the fictitious resumes actually exist in the respective city of birth. All candidates obtained their high-school leaving certificate (Abitur) in 2011. Resumes include the high-school GPA (Abiturnote).

All applicants have obtained a four-year Bachelor's degree in business administration at a public German university. The degrees are from universities ranked either in the top five or bottom five in the category undergraduate business degree of the CHE University Ranking 2015. Note that there are no tuition fees and typically no entrance exams for public colleges in Germany. Resumes include the college GPA.

High-school GPA and college GPA range from 1.3 to 3.3, that is, between very good and satisfactory. We do not use the best and worst possible grades to avoid very large (and quite uncommon) performance changes from high school to college. To avoid that one CV in a pair dominates on both GPAs, we randomize three of the four GPAs in each CV pair independently, but restrict the fourth GPA in a way that ensures that no CV contains better GPAs at both levels.

The area of the internship (sales, accounting, or controlling) is held constant within CV pairs in order not to give one candidate a particular advantage in case that the HR manager's 
firm happens to specialize in that area. Fictitious candidates have completed their internship at one of four existing mid-size firms that offer student internships on an online job portal.

All candidates have English language skills, but the level of proficiency varies between basic, very good, and fluent. Candidates may or may not have a second foreign language, either French or Spanish (basic level). All candidates are proficient in Microsoft Office, whereas some candidates have additional IT skills in both HTML and Dreamweaver.

\section{Appendix A3: Questionnaire}

HR managers are given the following questionnaire (translated from the original German version) after they have selected their preferred fictitious applicants.

1. How old are you? (drop down menu, 18-100 years)

2. You are: (male, female)

3. Which professional qualification do you have? (vocational degree, university of applied sciences degree, university degree, no professional degree, other degree)

4. Are you responsible for hiring decisions in your establishment? (yes, no)

5. Are you the managing director of the firm? (yes, no)

6. How many job interviews have you approximately conducted during the previous 12 months? $(0,1-9,10-50$, more than 50$)$

7. How important are for you the following characteristics of applicants in your firm? (very important, rather important, rather unimportant, very unimportant)

\section{$\underline{\text { All HR managers }}$}

- IT skills

- Language skills

- Professional experience through internships

- Hobbies

Only HR managers in secondary-school-graduate sample

- GPA of school-leaving degree

- German grade

- Math grade

Only HR managers in college-graduate sample

- High-school GPA (Abiturnote)

- College GPA 
Table A1: Values of All CV Elements of Secondary-School Graduates

\begin{tabular}{|c|c|c|c|c|}
\hline Gender* & Female & Male & & \\
\hline Male first name & Alexander & Christian & Daniel & Tobias \\
\hline Female first name & Sarah & Laura & Katharina & Julia \\
\hline Last name & Becker & Fischer & Schneider & Weber \\
\hline Date of birth & $15-$ Nov-98 & 22-Jan-99 & 12-Feb-99 & 10-Mar-99 \\
\hline School GPA & \multicolumn{4}{|c|}{$1.3 ; 1.7 ; 2.0 ; 2.3 ; 2.7 ; 3.0 ; 3.3$} \\
\hline Apprentice area* & commercial & technical & & \\
\hline Commercial internship & at Sparkasse & in bookstore & in hotel & $\begin{array}{l}\text { in supermar- } \\
\text { ket }\end{array}$ \\
\hline Technical internship f & $\begin{array}{l}\text { at hairdresser } \\
\text { salon }\end{array}$ & $\begin{array}{l}\text { at cosmetic at bakery } \\
\text { studio }\end{array}$ & at jeweller & $\begin{array}{l}\text { at photo- } \\
\text { graphic shop }\end{array}$ \\
\hline Technical internship $\mathbf{m}$ & $\begin{array}{l}\text { with floortiler } \\
\text { craftsman }\end{array}$ & at bakery at locksmith & with carpenter & at painter \\
\hline Internship length & 4 weeks & 2 weeks & & \\
\hline English & fluent & basic & & \\
\hline $2^{\text {nd }}$ foreign language & French & Spanish & & \\
\hline IT skills & $\begin{array}{l}\text { Microsoft Of- } \\
\text { fice }\end{array}$ & Microsoft Office, HTML and I & imweaver & \\
\hline Sports & single & team & & \\
\hline Single sports & swimming & running & & \\
\hline Team sports & handball & volleyball $\quad$ basketball & football & \\
\hline Social volunteering & $\begin{array}{l}\text { Neighbourhood } \\
\text { classes (social) }\end{array}$ & elp: youth and senior group, & man language & \\
\hline
\end{tabular}

Note: This table shows all values of all CV elements that were randomized. ${ }^{*}$ denotes elements that are fixed within CV pairs. School GPAs range from 1.3 (very good) to 3.3 (satisfactory); for the analysis grades are converted to points (4-grade). Technical internships vary for male and female candidates to ensure credibility. Each resume contains either two single sports or two team sports. In half of the resumes, there is no social volunteering. 
Table A2: Values of All CV Elements of College Graduates

\begin{tabular}{|c|c|c|c|c|c|c|c|}
\hline Gender* & Female & Male & & & & & \\
\hline Male first name & Alexander & Christian & Patrick & Daniel & Tobias & & \\
\hline Female first name & Sarah & Laura & Anna & Katharina & Julia & & \\
\hline Last name & Becker & Fischer & Mayer & Schneider & Weber & & \\
\hline Date of birth & 15-Nov-91 & 2-Dec-91 & 22-Jan-92 & 12-Feb-92 & 10-Mar-92 & & \\
\hline Place of birth & Wiesbaden & Erfurt & Mainz & Hannover & Düsseldorf & München & Stuttgart \\
\hline Type of secondary school* & catholic & $\begin{array}{l}\text { integrated } \\
\text { comprehen- } \\
\text { sive }\end{array}$ & neutral & & & & \\
\hline Catholic & $\begin{array}{l}\text { Bishop- } \\
\text { Naumann- } \\
\text { School } \\
\text { Königstein }\end{array}$ & $\begin{array}{l}\text { Edith-Stein- } \\
\text { School } \\
\text { Erfurt }\end{array}$ & $\begin{array}{l}\text { Theresianum, } \\
\text { Mainz }\end{array}$ & $\begin{array}{l}\text { Gymnasium } \\
\text { St.-Ursula- } \\
\text { School } \\
\text { Hannover }\end{array}$ & $\begin{array}{l}\text { Archiebiscopal } \\
\text { Suitbertus- } \\
\text { Gymnasium, } \\
\text { Düsseldorf }\end{array}$ & $\begin{array}{l}\text { Archiebiscopal } \\
\text { Maria- } \\
\text { Ward- } \\
\text { Gymnasium } \\
\text { München }\end{array}$ & $\begin{array}{l}1 \text { Sankt- } \\
\text { Meinrad- } \\
\text { Gymnasium }\end{array}$ \\
\hline Integrated comprehensive & $\begin{array}{l}\text { Helene } \\
\text { Lange } \\
\text { Gesamtschule } \\
\text { Wiesbaden }\end{array}$ & $\begin{array}{l}\text { Comprehensiv } \\
\text { secondary } \\
\text { Erfurt }\end{array}$ & $\begin{array}{l}\text { eComprehensive } \\
\text { secondary } \\
\text { Mainz- } \\
\text { Bretzenheim }\end{array}$ & $\begin{array}{l}\text { eComprehensiv } \\
\text { secondary } \\
\text { Linden, } \\
\text { Hannover }\end{array}$ & $\begin{array}{l}\text { eHeinrich- } \\
\text { Heine } \\
\text { Gesamtschule, } \\
\text { Düsseldorf }\end{array}$ & $\begin{array}{l}\text { Willy- } \\
\text { Brandt } \\
\text { Gesamtschule } \\
\text { München }\end{array}$ & $\begin{array}{l}\text { Elise von } \\
\text { König } \\
\text { Gemein- } \\
\text { schaftsschule }\end{array}$ \\
\hline Neutral & $\begin{array}{l}\text { Gymnasium } \\
\text { Leibniz } \\
\text { School } \\
\text { Wiesbaden }\end{array}$ & $\begin{array}{l}\text { Albert- } \\
\text { Schweizer } \\
\text { Gymnasium } \\
\text { Erfurt }\end{array}$ & $\begin{array}{l}\text { Gymnasium } \\
\text { Mainz- } \\
\text { Oberstadt }\end{array}$ & $\begin{array}{l}\text { Gymmasium } \\
\text { Schiller- } \\
\text { schule } \\
\text { Hannover }\end{array}$ & $\begin{array}{l}\text { Max-Planck } \\
\text { Gymnasium } \\
\text { Düsseldorf }\end{array}$ & $\begin{array}{l}\text { Oskar- } \\
\text { von-Miller } \\
\text { Gymnasium } \\
\text { München }\end{array}$ & $\begin{array}{l}\text { Karl- } \\
\text { Gymnasium } \\
\text { Stuttgart }\end{array}$ \\
\hline High-school GPA & 1.3 & 1.7 & 2.0 & 2.3 & 2.7 & 3.0 & 3.3 \\
\hline College type* & Top-ranked & $\begin{array}{ll}\text { Non } & \text { top- } \\
\text { ranked } & \end{array}$ & & & & & \\
\hline Top-ranked universities & $\begin{array}{l}\text { University of } \\
\text { Mannheim }\end{array}$ & $\begin{array}{l}\text { RWTH } \\
\text { Aachen }\end{array}$ & $\begin{array}{l}\text { University of } \\
\text { Munich }\end{array}$ & $\begin{array}{l}\text { University of } \\
\text { Cologne }\end{array}$ & $\begin{array}{l}\text { University of } \\
\text { Frankfurt }\end{array}$ & & \\
\hline Non top-ranked universities & $\begin{array}{l}\text { University of } \\
\text { Trier }\end{array}$ & $\begin{array}{l}\text { University of } \\
\text { Greifswald }\end{array}$ & $\begin{array}{l}\text { University of } \\
\text { Siegen }\end{array}$ & $\begin{array}{l}\text { University } \\
\text { Leuphana } \\
\text { Lüneburg }\end{array}$ & $\begin{array}{l}\text { University of } \\
\text { Bremen }\end{array}$ & & \\
\hline College GPA & 1.3 & 1.7 & 2.0 & 2.3 & 2.7 & 3.0 & 3.3 \\
\hline Internship firm & $\begin{array}{l}\text { Windmöller } \\
\& \text { Hölscher, } \\
\text { Lengerich }\end{array}$ & $\begin{array}{l}\text { Amann } \\
\text { Group, } \\
\text { Bönnigheim }\end{array}$ & $\begin{array}{l}\text { FACT, } \\
\text { Münster }\end{array}$ & $\begin{array}{l}\text { MVI Pro- } \\
\text { plant, Wolfs- } \\
\text { burg }\end{array}$ & $\begin{array}{l}\text { Astaro } \\
\text { GmbH \& } \\
\text { Co. KG, } \\
\text { Karlsruhe }\end{array}$ & & \\
\hline Internship business area* & Accounting & Controlling & Sales & & & & \\
\hline Internship length & 1 month & 3 months & 5 months & & & & \\
\hline English & fluent & very good & basic & & & & \\
\hline $2^{\text {nd }}$ foreign language & $\begin{array}{l}\text { Spanish (ba- } \\
\text { sic) }\end{array}$ & $\begin{array}{l}\text { French (ba- } \\
\text { sic) }\end{array}$ & & & & & \\
\hline IT skills & $\begin{array}{l}\text { Microsoft } \\
\text { Office }\end{array}$ & Microsoft Offi & ce, HTML and 1 & Dreamweaver & & & \\
\hline Sports & single & team & & & & & \\
\hline Single sports & swimming & cycling & running & & & & \\
\hline Team sports & handball & volleyall & basketball & football & & & \\
\hline Volunteering: "social" & $\begin{array}{l}\text { neighbourhood } \\
\text { senior group, } \\
\text { classes }\end{array}$ & $\begin{array}{l}\text { d help: yout } \\
\text {, German la }\end{array}$ & $\begin{array}{l}\mathrm{h} \text { and } \\
\text { nguage }\end{array}$ & $\begin{array}{l}\text { mobile care se } \\
\text { mestic care }\end{array}$ & rvices: senior an & nd do- & \\
\hline Volunteering: "non-social" & $\begin{array}{l}\text { volunteering } \mathrm{p} \\
\text { ments work }\end{array}$ & preservation of & monu- & $\begin{array}{l}\text { online volunte } \\
\text { and translatio }\end{array}$ & $\begin{array}{l}\text { ering at UN: IT } \\
\text { ns }\end{array}$ & work & \\
\hline
\end{tabular}


Table A3: Sample Representativeness: Comparing Respondents and Non-Respondents from the ifo Personnel Manager Survey Database

\begin{tabular}{lccc}
\hline \hline & Respondents & Non-respondents & p-value \\
\hline Assigned sample (secondary & 1.472 & 1.469 & .932 \\
school=1 / college=2) & .185 & .187 & .930 \\
Share female $\leq 20$ & & & .680 \\
Industry & 383.02 & 424.22 & .725 \\
Employees & & & .578 \\
State & .145 & .150 & \\
\hline Baden-Württemberg & .242 & .195 & \\
Bavaria & .009 & .023 & \\
Berlin & .019 & .023 & \\
Brandenburg & .007 & .011 & \\
Bremen & .021 & .024 & \\
Hamburg & .073 & .079 & \\
Hesse & .019 & .013 & \\
Mecklenburg-West Pomerania & .083 & .095 & \\
Lower Saxony & .181 & .178 & \\
North Rhine-Westphalia & .043 & .040 & \\
Rhineland-Palatinate & .012 & .009 & \\
Saarland & .074 & .066 & \\
Saxony & .021 & .028 & \\
Saxony Anhalt & .026 & .032 & \\
Schleswig-Holstein & .026 & .036 & \\
Thuringia & 579 & 927 & \\
\hline N (HR managers) & & & \\
\hline \hline
\end{tabular}

Note: Means and p-values from two-sided t-tests comparing respondents and non-respondents from the ifo Personnel Manager Survey Database. For "industry" and "state" distributions, both groups are compared using a two-sample Kolmogorov-Smirnov test (means are not reported for these categorical variables). Means for the German states represent the shares of firms from the respective state. 
Table A4: Invitation Rate by First and Last Names

\begin{tabular}{|c|c|c|c|c|c|c|}
\hline \multirow[b]{2}{*}{ Male first names } & \multicolumn{3}{|c|}{$\begin{array}{l}\text { Secondary-school } \\
\text { graduate sample }\end{array}$} & \multicolumn{3}{|c|}{$\begin{array}{l}\text { College-graduate } \\
\text { sample }\end{array}$} \\
\hline & mean & $\mathrm{p}$-value & $\mathrm{N}(\mathrm{CVs})$ & mean & p-value & $\mathrm{N}(\mathrm{CVs})$ \\
\hline Alexander & 0.408 & 0.039 & 125 & .558 & .241 & 104 \\
\hline Christian & 0.487 & 0.750 & 156 & .439 & .272 & 82 \\
\hline Daniel & 0.561 & 0.227 & 98 & .582 & .106 & 98 \\
\hline Patrick & 0.496 & 0.931 & 133 & .461 & .431 & 102 \\
\hline Tobias & 0.522 & 0.559 & 186 & .447 & .305 & 94 \\
\hline \multicolumn{7}{|l|}{ Female first names } \\
\hline Anna & 0.455 & 0.397 & 88 & .531 & .454 & 143 \\
\hline Julia & 0.554 & 0.239 & 121 & .463 & .419 & 123 \\
\hline Katharina & 0.480 & 0.657 & 125 & .510 & .844 & 102 \\
\hline Laura & 0.495 & 0.918 & 93 & .547 & .272 & 139 \\
\hline Sarah & 0.495 & 0.922 & 103 & .426 & .136 & 101 \\
\hline \multicolumn{7}{|l|}{ Last names } \\
\hline Becker & 0.480 & 0.525 & 246 & .463 & .275 & 214 \\
\hline Fischer & 0.482 & 0.554 & 284 & .559 & .091 & 202 \\
\hline Mayer & 0.538 & 0.217 & 262 & .589 & .005 & 241 \\
\hline Schneider & 0.474 & 0.428 & 228 & .403 & .003 & 226 \\
\hline Weber & 0.505 & 0.890 & 208 & .483 & .626 & 205 \\
\hline
\end{tabular}

Note: Mean represents the mean of the outcome of being selected for an interview. P-values stem from two-sided tests whether the mean of the outcome equals 0.5 . 
Figure A1: Example CV of a Secondary-School Graduate

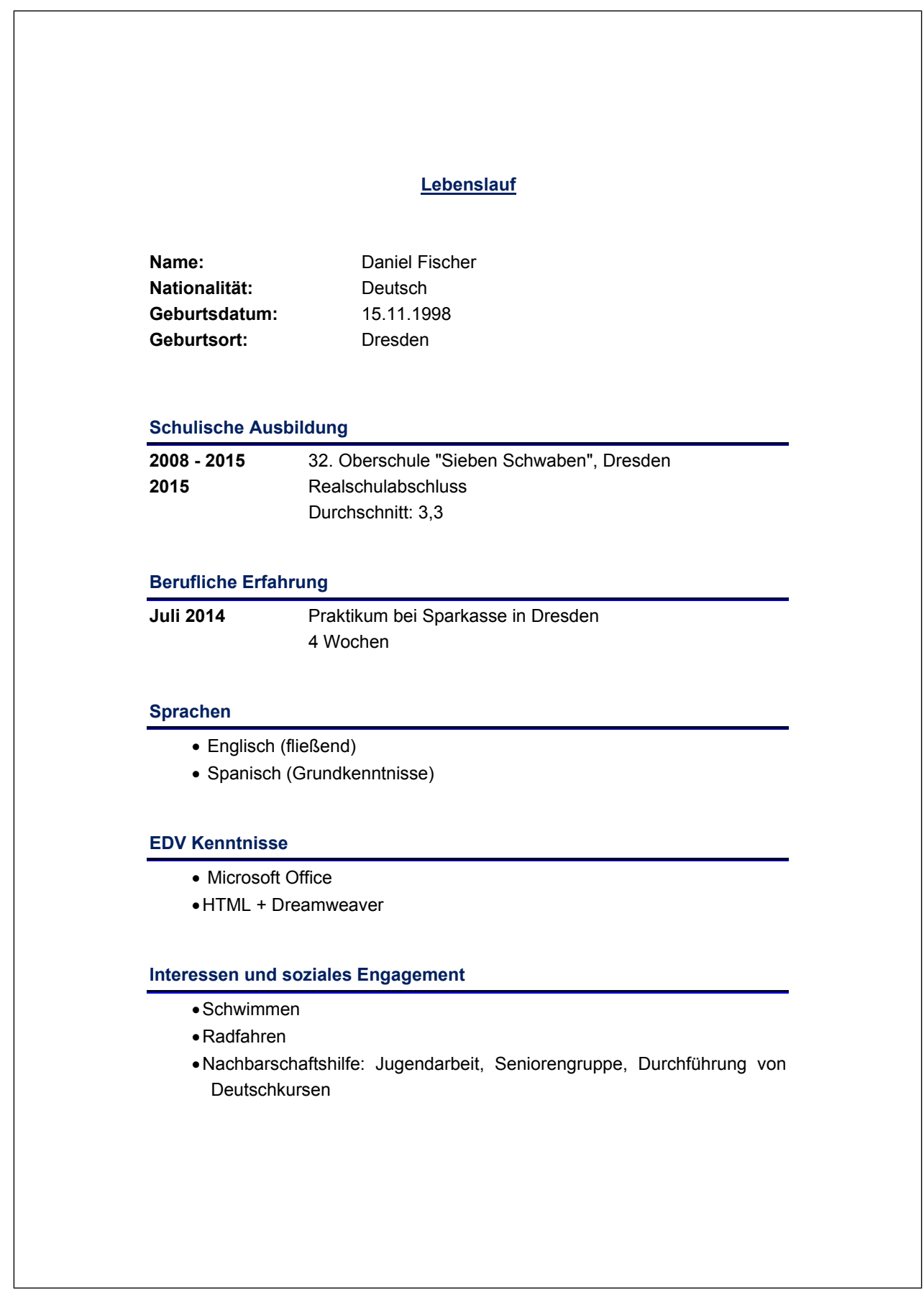


Figure A2: Example CV of a College Graduate

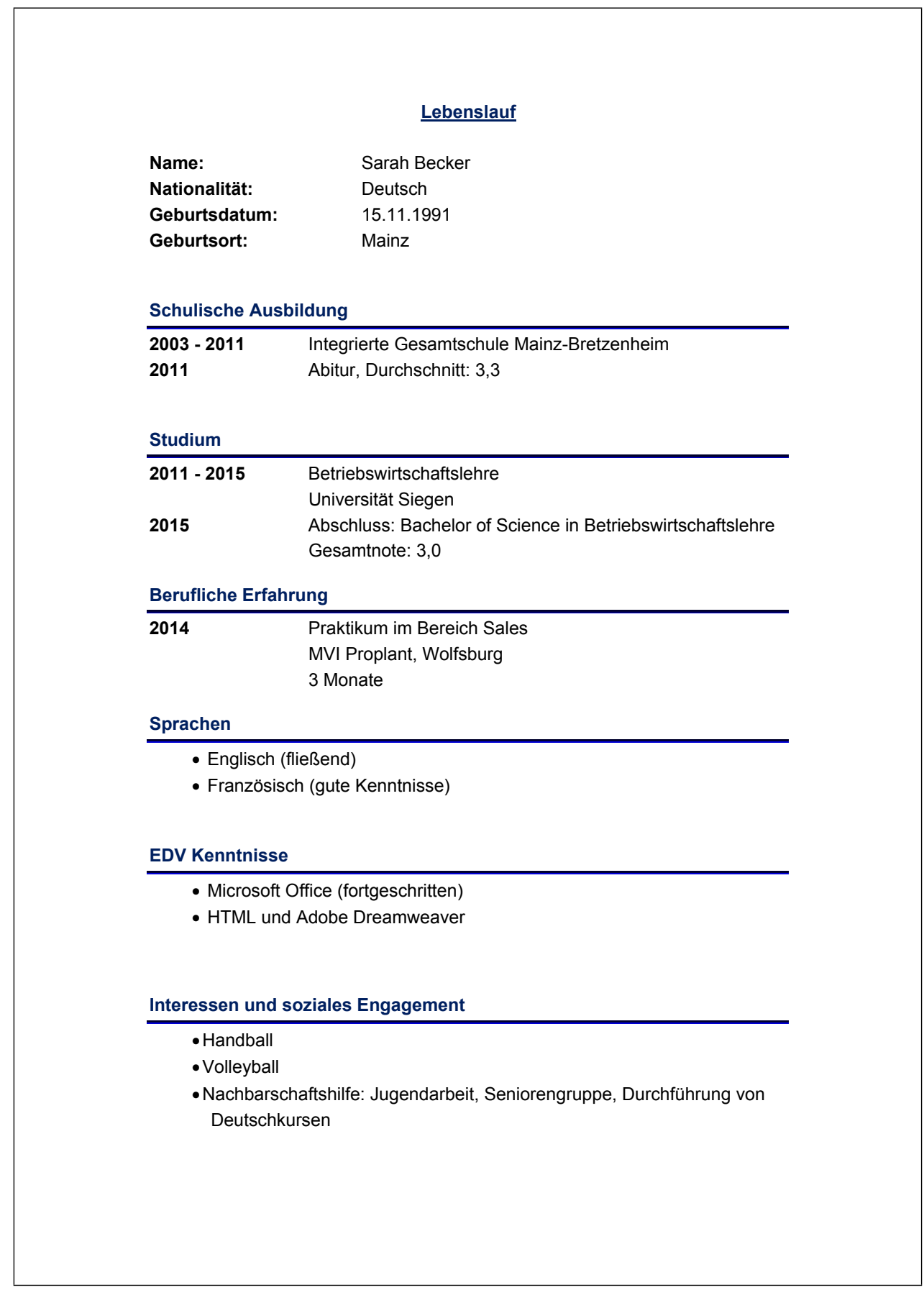


Table 1: Summary Statistics: Secondary-School Graduate CVs

\begin{tabular}{lcc}
\hline \hline & Mean & Std. Dev. \\
\hline Job interview invitation & .500 & \\
Cognitive Skills & & \\
School GPA & 1.460 & .628 \\
Extended IT skills & .491 & \\
Fluent English & .516 \\
French as 2 & .237 \\
Spanish as 2 language & .265 \\
Social Skills & \\
Social volunteering & .458 \\
Team sports & .500 \\
Maturity & \\
Age (earlier year in cohort) & .416 \\
Long internship & .514 \\
Non-varying Characteristics & \\
Male & .568 \\
Technical internship & .477 \\
State & \\
Baden-Wuerttemberg & .160 \\
Bavaria & .254 \\
Berlin & .003 \\
Brandenburg & .023 \\
Bremen & .007 \\
Hamburg & .020 \\
Hesse & .072 \\
Lower Saxony & .088 \\
Mecklenburg-Vorpommern & .013 \\
North Rhine-Westphalia & .178 \\
Rhineland-Palatinate & .024 \\
Saarland & .007 \\
Saxony & .088 \\
Saxony-Anhalt & .010 \\
Schleswig-Holstein & .020 \\
Thuringia & .036 \\
\hline N (CVs) & \\
\hline \hline Note: Means of CV elements of secondary-school graduates. All variables \\
except school GPA are binary. & \\
\end{tabular}


Table 2: Summary Statistics: College Graduate CVs

\begin{tabular}{|c|c|c|}
\hline & Mean & Std. Dev. \\
\hline Job interview invitation & .500 & \\
\hline \multicolumn{3}{|l|}{ Cognitive Skills } \\
\hline College GPA & 1.665 & .683 \\
\hline Extended IT skills & .500 & \\
\hline Very good English & .367 & \\
\hline Fluent English & .318 & \\
\hline French as $2^{\text {nd }}$ language & .267 & \\
\hline Spanish as $2^{\text {nd }}$ language & .245 & \\
\hline \multicolumn{3}{|l|}{ Social Skills } \\
\hline Social volunteering & .500 & \\
\hline Team sports & .500 & \\
\hline \multicolumn{3}{|l|}{ Maturity } \\
\hline High-school GPA & 1.677 & .674 \\
\hline Age (earlier year in cohort) & .380 & \\
\hline 3-months internship & .275 & \\
\hline 5-months internship & .330 & \\
\hline \multicolumn{3}{|l|}{ Non-varying Characteristics } \\
\hline Male & .441 & \\
\hline Catholic school & .360 & \\
\hline Comprehensive secondary & .353 & \\
\hline Top-ranked university & .553 & \\
\hline Internship in sales & .232 & \\
\hline Internship in controlling & .395 & \\
\hline \multicolumn{3}{|l|}{ College } \\
\hline University of Munich & .106 & \\
\hline RWTH Aachen & .092 & \\
\hline University Frankfurt & .110 & \\
\hline University Cologne & .132 & \\
\hline University Leuphana Lueneburg & .084 & \\
\hline Universiteat Mannheim & .113 & \\
\hline University Siegen & .098 & \\
\hline University Trier & .107 & \\
\hline University Bremen & .084 & \\
\hline \multicolumn{3}{|l|}{ High-school State } \\
\hline Baden-Wuerttemberg & .066 & \\
\hline Bavaria & .202 & \\
\hline Hesse & .132 & \\
\hline Lower Saxony & .153 & \\
\hline North Rhine-Westphalia & .172 & \\
\hline Rhineland-Palatinate & .128 & \\
\hline Thuringia & .147 & \\
\hline $\mathrm{N}(\mathrm{CVs})$ & & 1088 \\
\hline
\end{tabular}

Note: Means of CV elements of college graduates. All variables except GPAs are binary. 
Table 3: Skill Signals and Job-Interview Invitation:

Baseline Results for Secondary-School Graduates

\begin{tabular}{lccccc}
\hline \hline & $(1)$ & $(2)$ & $(3)$ & $(4)$ & $(5)$ \\
& All & All & Female & Male & All \\
\hline Cognitive Skills & & & & & \\
School GPA & $.22^{* * *}$ & $.21^{* * *}$ & .18 & $.24^{* *}$ & .22 \\
& $(.08)$ & $(.08)$ & $(.14)$ & $(.10)$ & $(.16)$ \\
Extended IT skills & $.17^{* * *}$ & $.16^{* * *}$ & $.22^{* *}$ & .14 & .20 \\
& $(.06)$ & $(.06)$ & $(.09)$ & $(.09)$ & $(.13)$ \\
Fluent English & $.12^{*}$ & $.12^{*}$ & .14 & .09 & .01 \\
& $(.06)$ & $(.07)$ & $(.10)$ & $(.09)$ & $(.13)$ \\
$2^{\text {nd }}$ foreign language & .04 & .05 & -.05 & .10 & -.02 \\
& $(.06)$ & $(.06)$ & $(.10)$ & $(.08)$ & $(.14)$ \\
Social Skills & & & & & \\
Social volunteering & $.37^{* * *}$ & $.36^{* * *}$ & $.38^{* * *}$ & $.36^{* * *}$ & $.50^{* * *}$ \\
& $(.07)$ & $(.07)$ & $(.10)$ & $(.08)$ & $(.14)$ \\
Team sports & .01 & .02 & .03 & -.01 & .09 \\
& $(.04)$ & $(.04)$ & $(.06)$ & $(.05)$ & $(.08)$ \\
Maturity & & & & & \\
Age & $.13^{* * *}$ & $.14^{* * *}$ & -.00 & $.24 * * *$ & .16 \\
& $(.05)$ & $(.05)$ & $(.08)$ & $(.07)$ & $(.10)$ \\
Long internship & .04 & .04 & .03 & .05 & .09 \\
& $(.06)$ & $(.06)$ & $(.09)$ & $(.09)$ & $(.13)$ \\
\hline Industry FE & No & Yes & Yes & Yes & \\
HR manager FE & No & No & No & No & Yes \\
\hline$R^{2}$ & .119 & .125 & .175 & .130 & .493 \\
N (CV pairs $)$ & 614 & 614 & 264 & 350 & 614 \\
\hline \hline Note: First-differenced model with CV pair as unit of observation. Dependent variable: \\
invitation for job interview. Standard errors clustered at HR-manager level in paren- \\
theses. Significance level: * p $<0.10, * *$ p $<0.05, * * *$ p $<0.01$. & & \\
& & & & &
\end{tabular}


Table 4: Skill Signals and Job-Interview Invitation:

Baseline Results for College Graduates

\begin{tabular}{lccccc}
\hline \hline & $(1)$ & $(2)$ & $(3)$ & $(4)$ & $(5)$ \\
& All & All & Female & Male & All \\
\hline Cognitive Skills & & & & & \\
College GPA & $.38^{* * *}$ & $.39^{* * *}$ & $.33^{* * *}$ & $.44^{* * *}$ & $.28^{* *}$ \\
& $(.07)$ & $(.07)$ & $(.11)$ & $(.09)$ & $(.14)$ \\
Extended IT skills & -.03 & -.02 & .02 & -.00 & -.02 \\
& $(.06)$ & $(.06)$ & $(.08)$ & $(.09)$ & $(.13)$ \\
English level & -.03 & -.03 & -.07 & -.01 & -.05 \\
& $(.04)$ & $(.04)$ & $(.05)$ & $(.06)$ & $(.07)$ \\
$2^{\text {nd }}$ foreign language & $.11^{*}$ & $.12^{* *}$ & $.25^{* * *}$ & -.04 & .05 \\
& $(.06)$ & $(.06)$ & $(.08)$ & $(.08)$ & $(.12)$ \\
Social Skills & & & & & \\
Social volunteering & .07 & .06 & $.10^{*}$ & -.00 & -.00 \\
& $(.05)$ & $(.05)$ & $(.06)$ & $(.07)$ & $(.10)$ \\
Team sports & $.10^{* *}$ & $.10^{* *}$ & $.11^{*}$ & .06 & $.16^{*}$ \\
& $(.04)$ & $(.04)$ & $(.06)$ & $(.07)$ & $(.09)$ \\
Maturity & & & & & \\
High-school GPA & .05 & .06 & -.02 & $.14^{*}$ & -.03 \\
& $(.05)$ & $(.05)$ & $(.07)$ & $(.08)$ & $(.11)$ \\
Age & .00 & .01 & .12 & -.08 & .03 \\
& $(.06)$ & $(.06)$ & $(.08)$ & $(.08)$ & $(.13)$ \\
Long internship & $.12^{* * *}$ & $.13^{* * *}$ & $.13^{* * *}$ & $.17^{* * *}$ & $.15^{* *}$ \\
& $(.03)$ & $(.03)$ & $(.05)$ & $(.05)$ & $(.06)$ \\
\hline Industry FE & No & Yes & Yes & Yes & \\
HR manager FE & No & No & No & No & Yes \\
\hline$R^{2}$ & .139 & .150 & .188 & .182 & .564 \\
N (CV pairs) & 544 & 544 & 304 & 240 & 544 \\
\hline \hline
\end{tabular}

Note: First-differenced model with CV pair as unit of observation. Dependent variable: invitation for job interview. Long internship refers to internship of three or five months (instead of only one month). Standard errors clustered at HR-manager level in parentheses. Significance level: ${ }^{*} \mathrm{p}<0.10,{ }^{* *} \mathrm{p}<0.05,{ }^{* * *} \mathrm{p}<0.01$. 
Table 5: Summary Statistics: HR Manager and Firm Characteristics

\begin{tabular}{|c|c|c|c|c|}
\hline & \multicolumn{2}{|c|}{$\begin{array}{l}\text { Secondary-school } \\
\text { graduates }\end{array}$} & \multicolumn{2}{|c|}{ College graduates } \\
\hline & Mean & Std. Dev. & Mean & Std. Dev. \\
\hline \multicolumn{5}{|l|}{ HR Manager Characteristics } \\
\hline Age & 49.944 & 10.0 & 49.664 & 9.8 \\
\hline Male & .658 & & .651 & \\
\hline Managing director & .437 & & .288 & \\
\hline Hiring responsibility & .875 & & .871 & \\
\hline \multicolumn{5}{|l|}{ Professional education level } \\
\hline Vocational education degree & .309 & & .217 & \\
\hline University of applied sciences degree & .250 & & .258 & \\
\hline University degree & .411 & & .472 & \\
\hline None/Other & .026 & & .051 & \\
\hline \multicolumn{5}{|l|}{ Firm Characteristics } \\
\hline Number of employees & 331 & 1286.7 & 442 & 1817.9 \\
\hline Industry share female employees $\leq 20 \%$ & .239 & & .118 & \\
\hline \multicolumn{5}{|l|}{ Industry } \\
\hline Manufacturing & .534 & & .360 & \\
\hline Trade, maintenance and reparations & .182 & & .136 & \\
\hline Hospitality & .032 & & .025 & \\
\hline Transport and communication & .072 & & .074 & \\
\hline Real estate & .162 & & .341 & \\
\hline Other public services & .016 & & .062 & \\
\hline $\mathrm{N}$ (HR managers) & 307 & & 272 & \\
\hline
\end{tabular}

Note: Means (and standard deviations for continuous variables) reported. HR manager characteristics come from the survey questionnaire and firm characteristics come from the ifo Personnel Manager Survey Database. "Industry share female employees $\leq 20 \%$ " refers to the share of firms in industries with less than $20 \%$ female employment. Indicated industries refer to the 1-digit German Classification of Economic Activity, Version 2003. 
Table 6: Interactions of Skill Signals with HR Manager and Firm Characteristics: Secondary-School Graduates

\begin{tabular}{|c|c|c|c|c|c|c|}
\hline & (1) & $(2)$ & $(3)$ & (4) & $(5)$ & $(6)$ \\
\hline & $\begin{array}{c}\text { HR age } \\
\text { above median }\end{array}$ & Male & $\begin{array}{l}\text { Managing } \\
\text { director }\end{array}$ & $\begin{array}{c}\text { Hiring } \\
\text { responsibility }\end{array}$ & $\begin{array}{l}\text { Technical } \\
\text { sector }\end{array}$ & $\begin{array}{l}\text { Firm size } \\
\geq 250 \\
\text { employees }\end{array}$ \\
\hline \multicolumn{7}{|l|}{ Cognitive Skills } \\
\hline School GPA & $\begin{array}{c}-.22^{* *} \\
(.10)\end{array}$ & $\begin{array}{c}.04 \\
(.11)\end{array}$ & $\begin{array}{c}-.33^{* * *} \\
(.09)\end{array}$ & $\begin{array}{l}-.24 \\
(.16)\end{array}$ & $\begin{array}{l}.16^{*} \\
(.10)\end{array}$ & $\begin{array}{l}.03 \\
(.12)\end{array}$ \\
\hline Extended IT skills & $\begin{array}{l}.19^{*} \\
(.10)\end{array}$ & $\begin{array}{l}.16 \\
(.10)\end{array}$ & $\begin{array}{c}.26^{* * *} \\
(.10)\end{array}$ & $\begin{array}{l}.21 \\
(.15)\end{array}$ & $\begin{array}{c}-.21^{* *} \\
(.10)\end{array}$ & $\begin{array}{l}-.01 \\
(.12)\end{array}$ \\
\hline Fluent English & $\begin{array}{l}.09 \\
(.10)\end{array}$ & $\begin{array}{l}-.08 \\
(.10)\end{array}$ & $\begin{array}{l}.10 \\
(.10)\end{array}$ & $\begin{array}{l}.12 \\
(.15)\end{array}$ & $\begin{array}{l}-.12 \\
(.10)\end{array}$ & $\begin{array}{l}.11 \\
(.13)\end{array}$ \\
\hline $2^{\text {nd }}$ foreign language & $\begin{array}{l}.10 \\
(.10)\end{array}$ & $\begin{array}{l}.19^{*} \\
(.11)\end{array}$ & $\begin{array}{l}.24^{* *} \\
(.10)\end{array}$ & $\begin{array}{l}.21 \\
(.14)\end{array}$ & $\begin{array}{c}-.22^{* *} \\
(.10)\end{array}$ & $\begin{array}{l}-.02 \\
(.12)\end{array}$ \\
\hline \multicolumn{7}{|l|}{ Social Skills } \\
\hline Social volunteering & $\begin{array}{l}.22^{* *} \\
(.11)\end{array}$ & $\begin{array}{l}.06 \\
(.12)\end{array}$ & $\begin{array}{l}.24^{* *} \\
(.11)\end{array}$ & $\begin{array}{l}.20 \\
(.18)\end{array}$ & $\begin{array}{l}-.19^{*} \\
(.11)\end{array}$ & $\begin{array}{l}-.10 \\
(.13)\end{array}$ \\
\hline Team sports & $\begin{array}{c}-.16^{* *} \\
(.08)\end{array}$ & $\begin{array}{l}.08 \\
(.08)\end{array}$ & $\begin{array}{l}-.05 \\
(.08)\end{array}$ & $\begin{array}{l}.12 \\
(.12)\end{array}$ & $\begin{array}{l}.02 \\
(.08)\end{array}$ & $\begin{array}{l}.14 \\
(.09)\end{array}$ \\
\hline \multicolumn{7}{|l|}{ Maturity } \\
\hline Age & $\begin{array}{l}-.01 \\
(.10)\end{array}$ & $\begin{array}{l}.03 \\
(.11)\end{array}$ & $\begin{array}{l}-.02 \\
(.10)\end{array}$ & $\begin{array}{l}.07 \\
(.16)\end{array}$ & $\begin{array}{l}-.14 \\
(.10)\end{array}$ & $\begin{array}{l}.03 \\
(.12)\end{array}$ \\
\hline Long internship & $\begin{array}{l}.11 \\
(.10)\end{array}$ & $\begin{array}{l}.03 \\
(.11)\end{array}$ & $\begin{array}{l}.21^{* *} \\
(.10)\end{array}$ & $\begin{array}{l}.27^{*} \\
(.16)\end{array}$ & $\begin{array}{c}-.23^{* *} \\
(.10)\end{array}$ & $\begin{array}{l}.12 \\
(.13)\end{array}$ \\
\hline
\end{tabular}

Note: Each cell stems from a separate regression. The reported coefficients are the interaction terms between the two elements indicated in the header and first column. First-differenced model with CV pair as unit of observation. Dependent variable: invitation for job interview. Controls for other CV elements as in Table 3 included throughout. All regressions include industry fixed effects. Standard errors clustered at HR-manager level in parentheses. Significance level: ${ }^{*} \mathrm{p}<0.10,{ }^{* *} \mathrm{p}<0.05,{ }^{* * *}$ $\mathrm{p}<0.01$. 
Table 7: Interactions of Skill Signals with HR Manager and Firm Characteristics: College Graduates

\begin{tabular}{|c|c|c|c|c|c|c|c|}
\hline & (1) & $(2)$ & $(3)$ & (4) & $(5)$ & (6) & $(7)$ \\
\hline & $\begin{array}{c}\text { HR age } \\
\text { above median }\end{array}$ & Male & $\begin{array}{l}\text { Managing } \\
\text { director }\end{array}$ & $\begin{array}{c}\text { Hiring } \\
\text { responsibility }\end{array}$ & $\begin{array}{l}\text { Vocational } \\
\text { degree }\end{array}$ & $\begin{array}{c}\text { Technical } \\
\text { college degree }\end{array}$ & $\begin{array}{l}\text { Firm size } \\
\quad \geq 250 \\
\text { employees }\end{array}$ \\
\hline \multicolumn{8}{|l|}{ Cognitive Skills } \\
\hline College GPA & $\begin{array}{l}-.06 \\
(.11)\end{array}$ & $\begin{array}{l}-.13 \\
(.10)\end{array}$ & $\begin{array}{l}-.17 \\
(.13)\end{array}$ & $\begin{array}{l}-.05 \\
(.12)\end{array}$ & $\begin{array}{l}.18 \\
(.11)\end{array}$ & $\begin{array}{c}-.31^{* * *} \\
(.11)\end{array}$ & $\begin{array}{l}.23^{* *} \\
(.10)\end{array}$ \\
\hline Extended IT skills & $\begin{array}{l}.16 \\
(.12)\end{array}$ & $\begin{array}{l}.08 \\
(.13)\end{array}$ & $\begin{array}{l}-.03 \\
(.13)\end{array}$ & $\begin{array}{l}.18 \\
(.18)\end{array}$ & $\begin{array}{l}.15 \\
(.15)\end{array}$ & $\begin{array}{c}.01 \\
(.14)\end{array}$ & $\begin{array}{c}.19 \\
(.14)\end{array}$ \\
\hline English level & $\begin{array}{l}-.03 \\
(.07)\end{array}$ & $\begin{array}{l}-.07 \\
(.07)\end{array}$ & $\begin{array}{c}-.14^{*} \\
(.08)\end{array}$ & $\begin{array}{c}.04 \\
(.10)\end{array}$ & $\begin{array}{c}.02 \\
(.08)\end{array}$ & $\begin{array}{c}.06 \\
(.08)\end{array}$ & $\begin{array}{l}.08 \\
(.08)\end{array}$ \\
\hline $2^{\text {nd }}$ foreign language & $\begin{array}{l}.25^{* *} \\
(.12)\end{array}$ & $\begin{array}{l}.26^{* *} \\
(.12)\end{array}$ & $\begin{array}{l}.20 \\
(.13)\end{array}$ & $\begin{array}{l}.29^{* *} \\
(.14)\end{array}$ & $\begin{array}{l}-.20 \\
(.14)\end{array}$ & $\begin{array}{l}-.16 \\
(.14)\end{array}$ & $\begin{array}{c}-.31^{* *} \\
(.13)\end{array}$ \\
\hline \multicolumn{8}{|l|}{ Social Skills } \\
\hline Social volunteering & $\begin{array}{l}-.05 \\
(.09)\end{array}$ & $\begin{array}{c}.04 \\
(.09)\end{array}$ & $\begin{array}{l}-.13 \\
(.10)\end{array}$ & $\begin{array}{l}.16 \\
(.11)\end{array}$ & $\begin{array}{l}-.11 \\
(.10)\end{array}$ & $\begin{array}{l}.23^{* *} \\
(.10)\end{array}$ & $\begin{array}{l}-.11 \\
(.10)\end{array}$ \\
\hline Team sports & $\begin{array}{l}.10 \\
(.08)\end{array}$ & $\begin{array}{l}.00 \\
(.09)\end{array}$ & $\begin{array}{l}-.02 \\
(.09)\end{array}$ & $\begin{array}{l}-.07 \\
(.12)\end{array}$ & $\begin{array}{l}.00 \\
(.10)\end{array}$ & $\begin{array}{l}.27^{* * *} \\
(.09)\end{array}$ & $\begin{array}{l}.06 \\
(.10)\end{array}$ \\
\hline \multicolumn{8}{|l|}{ Maturity } \\
\hline High-school GPA & $\begin{array}{c}.05 \\
(.08)\end{array}$ & $\begin{array}{c}.11 \\
(.08)\end{array}$ & $\begin{array}{l}-.06 \\
(.1)\end{array}$ & $\begin{array}{l}-.11 \\
(.1)\end{array}$ & $\begin{array}{c}-.21^{* *} \\
(.09)\end{array}$ & $\begin{array}{c}.14 \\
(.10)\end{array}$ & $\begin{array}{l}0.00 \\
(.11)\end{array}$ \\
\hline Age & $\begin{array}{c}.01 \\
(.11)\end{array}$ & $\begin{array}{l}.00 \\
(.11)\end{array}$ & $\begin{array}{c}.01 \\
(.14)\end{array}$ & $\begin{array}{c}.03 \\
(.14)\end{array}$ & $\begin{array}{l}-.10 \\
(.12)\end{array}$ & $\begin{array}{c}.04 \\
(.13)\end{array}$ & $\begin{array}{c}.02 \\
(.13)\end{array}$ \\
\hline Long internship & $\begin{array}{l}-.06 \\
(.06)\end{array}$ & $\begin{array}{l}-.07 \\
(.07)\end{array}$ & $\begin{array}{c}-.16^{* *} \\
(.07)\end{array}$ & $\begin{array}{l}-.14^{*} \\
(.07)\end{array}$ & $\begin{array}{c}.08 \\
(.07)\end{array}$ & $\begin{array}{l}-.05 \\
(.07)\end{array}$ & $\begin{array}{c}.01 \\
(.07)\end{array}$ \\
\hline
\end{tabular}


Table 8: HR Managers' Stated Priorities: Survey Results

\begin{tabular}{lcccc}
\hline \hline & \multicolumn{2}{c}{ HR manager sample } & & \\
\cline { 2 - 3 } & $\begin{array}{c}\text { Secondary-school } \\
\text { graduates }\end{array}$ & $\begin{array}{c}\text { College } \\
\text { graduates }\end{array}$ & $\begin{array}{c}\text { Difference } \\
(1)-(2)\end{array}$ & p-value \\
\hline School GPA & $(1)$ & $(2)$ & $(3)$ & $(4)$ \\
College GPA & .668 & .469 & .199 & .000 \\
German grade & $\mathrm{n} / \mathrm{a}$ & .808 & $\mathrm{n} / \mathrm{a}$ & $\mathrm{n} / \mathrm{a}$ \\
Math grade & .806 & $\mathrm{n} / \mathrm{a}$ & $\mathrm{n} / \mathrm{a}$ & $\mathrm{n} / \mathrm{a}$ \\
IT skills & .885 & $\mathrm{n} / \mathrm{a}$ & $\mathrm{n} / \mathrm{a}$ & $\mathrm{n} / \mathrm{a}$ \\
Language skills & .858 & .956 & -.098 & .000 \\
Professional experience & .657 & .828 & -.172 & .000 \\
through internships & .736 & .941 & -.205 & .000 \\
Hobbies & .483 & .472 & .011 & .593 \\
\hline N (HR managers) & 307 & 272 & & \\
\hline \hline
\end{tabular}

Note: Shares of HR managers stating to find the indicated characteristic "very important" or "rather important". p-values in column (4) stem from a two-sided t-test. 
Table 9: Interactions of Skill Signals with HR Manager Priorities: Secondary-School Graduates

\begin{tabular}{lccccc}
\hline \hline & $(1)$ & $\begin{array}{c}(2) \\
\text { School GPA } \\
\text { IT skills }\end{array}$ & $\begin{array}{c}(3) \\
\text { Fluent } \\
\text { English }\end{array}$ & $\begin{array}{c}(4) \\
2^{\text {nd }} \\
\text { language } \\
\text { foreign }\end{array}$ & $\begin{array}{c}(5) \\
\text { Long } \\
\text { internship }\end{array}$ \\
\hline CV element & $.21^{* * *}$ & $.16^{* *}$ & $.13^{* *}$ & .06 & .04 \\
Interaction & $(.07)$ & $(.06)$ & $(.07)$ & $(.06)$ & $(.06)$ \\
with HR priority & $.36^{* * *}$ & $.27^{* * *}$ & $.32^{* * *}$ & $.27^{* * *}$ & $.18^{* *}$ \\
& $(.07)$ & $(.08)$ & $(.06)$ & $(.06)$ & $(.08)$ \\
\hline Controls for & Yes & Yes & Yes & Yes & Yes \\
other CV elements & Yes & Yes & Yes & Yes & Yes \\
Industry FE & .171 & .152 & .175 & .163 & .143 \\
\hline$R^{2}$ & 601 & 605 & 605 & 605 & 605 \\
$\mathrm{~N}$ (CV pairs) & & & & &
\end{tabular}

Note: First-differenced model with $\mathrm{CV}$ pair as unit of observation. Dependent variable: invitation for job interview. Controls for other CV elements as in Table 3 included throughout. HR priority refers to importance given to the respective CV element (on a 4-point scale) by the HR manager in the questionnaire ( $1=$ very unimportant, $2=$ rather unimportant, $3=$ rather important, $4=$ very important). In columns 3 and 4, this importance refers to "language skills", in column 5 to "professional experience through internships." Standard errors clustered at HR-manager level in parentheses. Significance level: ${ }^{*} \mathrm{p}<0.10,{ }^{* *} \mathrm{p}<0.05,{ }^{* * *}$ $\mathrm{p}<0.01$. 
Table 10: Interactions of Skill Signals with HR Manager Priorities: College Graduates

\begin{tabular}{lcccccc}
\hline \hline & $\begin{array}{c}(1) \\
\text { College } \\
\text { GPA }\end{array}$ & $\begin{array}{c}(2) \\
\text { Extended } \\
\text { IT skills }\end{array}$ & $\begin{array}{c}(3) \\
\text { English } \\
\text { level }\end{array}$ & $\begin{array}{c}(4) \\
2^{\text {nd }} \text { foreign } \\
\text { language }\end{array}$ & $\begin{array}{c}(5) \\
\text { High-school } \\
\text { GPA }\end{array}$ & $\begin{array}{c}\text { Long } \\
\text { internship }\end{array}$ \\
\hline CV element & $.43^{* * *}$ & .02 & .05 & $.12^{* *}$ & .08 & $.26^{* * *}$ \\
Interaction with & $(.07)$ & $(.06)$ & $(.07)$ & $(.06)$ & $(.05)$ & $(.06)$ \\
HR priority & $.27^{* * *}$ & $.23^{* *}$ & $.18^{* *}$ & .12 & .08 & .02 \\
& $(.08)$ & $(.12)$ & $(.09)$ & $(.08)$ & $(.07)$ & $(.10)$ \\
\hline Controls for & Yes & Yes & Yes & Yes & Yes & Yes \\
other CV elements & Yes & Yes & Yes & Yes & Yes & Yes \\
Industry FE & .168 & .163 & .171 & .168 & .156 & .154 \\
\hline$R^{2}$ & 542 & 542 & 536 & 536 & 542 & 542 \\
$\mathrm{~N}$ (CV pairs) &
\end{tabular}

Note: First-differenced model with CV pair as unit of observation. Dependent variable: invitation for job interview. Long internship refers to internship of three or five months (instead of only one month). Controls for other CV elements as in Table 4 included throughout. HR priority refers to importance given to the respective CV element (on a 4-point scale) by the HR manager in the questionnaire ( $1=$ very unimportant, $2=$ rather unimportant, $3=$ rather important, $4=$ very important). In columns 3 and 4, this importance refers to "language skills", in column 6 to "professional experience through internships". Standard errors clustered at HR-manager level in parentheses. Significance level: * $\mathrm{p}<0.10,{ }^{* *} \mathrm{p}<0.05, * * * \mathrm{p}<0.01$. 


\section{CVER PUBLICATIONS}

\section{Research Papers}

Building apprentices' skills in the workplace: Car Service in Germany, the UK and Spain, CVER Research Paper 011, December 2017

Philipp Grollmann, Hilary Steedman, Anika Jansen and Robert Gray

Apprenticeships for Young People in England: Is there a Payoff? CVER Research Paper 010, November 2017 Chiara Cavaglia, Sandra McNally and Guglielmo Ventura

The Payoff to Vocational Qualifications: Reconciling Estimates from Survey and Administrative Data, CVER Research Paper 009, November 2017

Gavan Conlon, Sophie Hedges, Steven McIntosh, Damon Morris and Pietro Patrignani

Peer Effects and Social Influence in Post-16 Educational Choice, CVER Research Paper 008, November 2017 Sophie Hedges and Stefan Speckesser,

The earnings differentials associated with vocational education and training using the Longitudinal Education Outcomes data, CVER Research Paper 008, October 2017

Gavan Conlon, Sophie Hedges and Pietro Patrignani

The longer the better? The impact of the 2012 apprenticeship reform in England on achievement and other outcomes, CVER Research Paper 006, September 2017

Vahé Nafilyan and Stefan Speckesser

Post 16 remedial policies: a literature review, CVER Research Paper 005, April 2017

Clémentine Van Effenterre

Young people in low level vocational education: characteristics, trajectories and labour market outcomes CVER Research Paper 004, March 2017

Sophie Hedges, Vahé Nafilyan, Stefan Speckesser and Augustin de Coulon

Vocational vs. General Education and Employment over the Life-Cycle: New Evidence from PIAAC CVER Research Paper 003, November 2016

Franziska Hampf and Ludger Woessmann

Labour Market Returns to Vocational Qualifications in the Labour Force Survey, CVER Research Paper 002, October 2016

Steven McIntosh and Damon Morris

Post-Compulsory Education in England: Choices and Implications, CVER Research Paper 001, July 2016 Claudia Hupkau, Sandra McNally, Jenifer Ruiz-Valenzuela and Guglielmo Ventura 


\section{Briefing Notes}

Effectiveness of CEOs in the Public Sector: Evidence from Further Education Institutions, CVER Briefing Note 005, December 2017

Jenifer Ruiz-Valenzuela, Camille Terrier, Clémentine Van-Effenterre

An analysis of the duration and achievement of apprenticeships in England, CVER Briefing Note 004, September 2017

Matthew Bursnall, Vahé Nafilyan, Stefan Speckesser

The incidence of publicly funded training in England, CVER Briefing Note 003, March 2017

Gavan Conlon, Sophie Hedges, Daniel Herr and Pietro Patrignani

The Decision to Undertake an Apprenticeship: A Case Study, CVER Briefing Note 002, March 2017 Steven McIntosh

Further Education in England: Learners and Institutions, CVER Briefing Note 001, February 2017 Claudia Hupkau and Guglielmo Ventura

http://cver.Ise.ac.uk 